\title{
Review
}

\section{Intracellular signaling mechanisms in photodynamic therapy}

\author{
Ramiro D. Almeida, Bruno J. Manadas, Arsélio P. Carvalho, Carlos B. Duarte* \\ Center for Neuroscience and Cell Biology, Department of Zoology, University of Coimbra, Coimbra, 3004-517 Portugal
}

Received 14 January 2004; received in revised form 26 May 2004; accepted 28 May 2004

Available online 21 June 2004

\begin{abstract}
In photodynamic therapy (PDT) a sensitizer, light and oxygen are used to induce death of tumor cells and in the treatment of certain noncancerous conditions. Cell death in PDT may occur by apoptosis or by necrosis, depending on the sensitizer, on the PDT dose and on the cell genotype. Some sensitizers that have been used in PDT are accumulated in the mitochondria, and this may explain their efficiency in inducing apoptotic cell death, both in vitro and in vivo. In this review we will focus on the events that characterize apoptotic death in PDT and on the intracellular signaling events that are set in motion in photosensitized cells. Activation of phospholipases, changes in ceramide metabolism, a rise in the cytosolic free $\mathrm{Ca}^{2+}$ concentration, stimulation of nitric oxide synthase (NOS), changes in protein phosphorylation and alterations in the activity of transcription factors and on gene expression have all been observed in PDT-treated cells. Although many of these metabolic reactions contribute to the demise process, some of them may antagonize cell death. Understanding the signaling mechanisms in PDT may provide means to modulate the PDT effects at the molecular level and potentiate its antitumor effectiveness.
\end{abstract}

(C) 2004 Elsevier B.V. All rights reserved.

Keywords: Photodynamic therapy; Apoptosis; Necrosis; Calcium; Phosphorylation

Abbreviations: AIF, apoptosis-inducing factor; ALA, 5-aminolevulinate; AlPc, chloroaluminum phthalocyanine; AlPcS ${ }_{2}$, bisulfonated aluminum phthalocyanine; $\mathrm{AlPcS}_{4}$, tetrasulfonated aluminum phthalocyanine; ANT, adenine nucleotide translocator; AP-1, transcription factor activator protein-1; Apaf-1, apoptotic protease activating factor-1; APP, aminopyropheophorbide; ATX-S10, 13,17-bis(1-carboxypropionyl)carbamoylethyl-8-ethenyl-2-hydroxy3-hydroxyiminoethylidene-2,7,12,18-tetramethylporphyrin; 2-BA-2-DMHA, 2-butylamino-2-demethoxy-hypocrellin $\mathrm{A}$, $\mathrm{Bid}, \mathrm{BH}_{3}$-interacting domain death agonist; BPD-MA, benzoporphyrin derivative monoacid ring A (verteporfin); CARD, caspase-recruitment domain; CDK, cyclin-dependent protein kinase; COX, cyclooxygenase; CPO, 9-capronyloxy-tetrakis (methoxyethyl) porphycene; CrmA, viral cytokine response modifier A; DIABLO, direct inhibitor of apoptosis-binding protein with low $\mathrm{p} I$; DNA-PK $\mathrm{CS}_{\mathrm{CS}}$, DNA-dependent protein kinase (catalytic subunit); E2F, E2F family of transcription factors; EGF, epidermal growth factor; EGFR, EGF receptor; ER, endoplasmic reticulum; ERK, extracellular signal-regulated kinase; Etk/Bmx, epithelial and endothelial tyrosine kinase or bone marrow tyrosine kinase gene in chromosome X; FADD, Fas-associated protein with a death domain; FAK, focal adhesion kinase; FasL, Fas ligand; GFP, green fluorescent protein; GRP, glucose-regulated proteins; HPD, haematoporphyrin derivative; HPMA, N-(2-hydroxypropyl)methacrylamide; HPPH, 2-[1-hexyloxyethyl]-2-devinyl pyropheophorbide-a; HS1, haematopoietic lineage cell-specific protein 1; HSE, heat-shock elements; HSF, heat-shock factors; HSP, heat-shock protein; IAP, inhibitor of apoptosis; ICAD, inhibitor of caspase activated DNAse; IL, interleukin; Ins(1,4,5) $\mathrm{P}_{3}$, inositol 1,4,5-trisphosphate; JAK, Janus kinase; JNK/SAPK, c-Jun N-terminal kinase/stress activated protein kinase; LIF, leukemia inhibitory factor; LIFR, LIF receptor; LFS, Li-Fraumeni syndrome; MAPK, mitogen-activated protein kinase; Mce $_{6}$, mesochlorine $\mathrm{e}_{6}$ monoethylenediamine; MIP-2, macrophage inflammatory protein-2; MKP-1, mitogen-activated protein kinase phosphatase 1; MMP, matrix metalloproteinases; MPTP, mitochondrial permeability transition pore; NADPH-d, nicotinamide adenine dinucleotide hydrogen phosphate-diaphorase; mTHPC, meso-tetrahydroxyphenyl chlorin (Foscan $\left.{ }^{\circledR}\right)$; NOS, nitric oxide synthase; NF-kB, nuclear factor kappa B; Npe6, mono-L-aspartyl chlorin $\mathrm{e}_{6}$; OSMR $\beta$, oncostatin receptor- $\beta$; PARP, poly(ADP-ribose) polymerase; Pc 4, silicon phthalocyanine 4; PDT, photodynamic therapy; PF, proflavine; PG, prostaglandin; PI3-K, phosphatidylinositol-3-kinase; PI-PLC, phosphatidylinositol-4,5-bisphosphate-specific phospholipase C; PKB, protein kinase B; PKC, protein kinase C; PPME, pyropheophorbide-a methyl ester; $\psi_{\mathrm{m}}$, mitochondrial membrane potential; Rb, retinoblastoma; SERCA, sarco/endoplasmic reticulum $\mathrm{Ca}^{2+}$ ATPase; Smac, second mitochondria-derived activator of caspase; SOD, superoxide dismutase; STAT, signal transducers and activators of transcription; TB, thromboxane; tBid, truncated form of Bid; TBR, 2,4,5,7-tetrabromorhodamine 123 bromide; TNF, tumor necrosis factor; TPA, 12-O-tetradecanoylphorbol-13-acetate; VDAC, voltage-dependent anion channel; VEGF, the vascular endothelial growth factor

* Corresponding author. Tel.: +351-239-480209; fax: +351-239-480208.

E-mail address: cbduarte@ci.uc.pt (C.B. Duarte). 


\section{Contents}

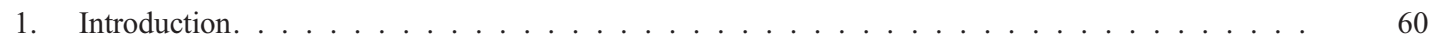

2. Mechanisms of cell death in PDT . . . . . . . . . . . . . . . . . . . . 61

2.1. Apoptotic cell death in PDT . . . . . . . . . . . . . . . . . . . 61

2.1.1. Death receptor-mediated apoptosis in PDT . . . . . . . . . . . . . . . . . 61

2.1.2. Mitochondria-mediated apoptosis in PDT . . . . . . . . . . . . 62

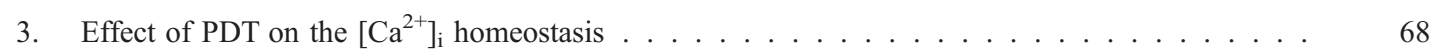

4. Activation of lipid metabolism by PDT . . . . . . . . . . . . . . . . . . . . 70

4.1. Phosphatidylinositol-specific phospholipase C (PI-PLC) . . . . . . . . . . . . . 70

4.2. Phopholipase $\mathrm{A}_{2}$ and arachidonic acid metabolites . . . . . . . . . . . . . . . 70

4.3. Ceramide ......................... . . . 70

5. Role of cyclic nucleotides in PDT . . . . . . . . . . . . . . . . . . . . . . . 72

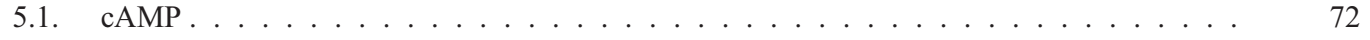

5.2. Nitric oxide and cGMP . . . . . . . . . . . . . . . . . . . . 72

6. Role of MAPKs and CDKs in PDT . . . . . . . . . . . . . . . . . . 72

7. Differential effect of PDT on tyrosine kinases . . . . . . . . . . . . . . . . . 73

8. Regulation of transcription factors in PDT . . . . . . . . . . . . . . . . . . . . . 74

8.1. Transcription factor activator protein-1 (AP-1) . . . . . . . . . . . . . . . 74

8.2. Transcription nuclear factor kappa B (NF-kB) . . . . . . . . . . . . . . . . . . . . 75

8.3. Retinoblastoma $(\mathrm{Rb})$ and $\mathrm{E} 2 \mathrm{~F}$ family of transcription factors. . . . . . . . . . . . . 75

9. Changes in protein levels in response to PDT . . . . . . . . . . . . . . . . 76

9.1. Heme oxygenase . . . . . . . . . . . . . . . . . . . . . . 76

9.2. Glucose-regulated proteins . . . . . . . . . . . . . . . . . . . . . . . 76

9.3. Heat-shock proteins . . . . . . . . . . . . . . . . . . . . . . . . . 76

9.4. Anti-oxidant enzymes and apoptosis regulatory proteins . . . . . . . . . . . . . . . . 77

9.5. Clusterin . . . . . . . . . . . . . . . . . . . . . . . . 77

9.6.

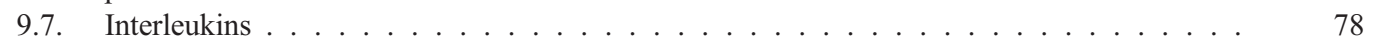

9.8. Regulators of angiogenesis . . . . . . . . . . . . . . . . . 78

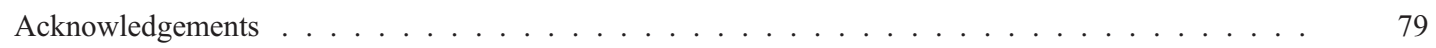

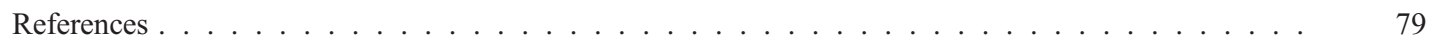

\section{Introduction}

Photodynamic therapy (PDT) of cancer is based on the tumor-specific accumulation of a photosensitizer, often a porphyrin derivative, followed by irradiation with visible light, which induces cell death and tumor ablation. Photofrin ${ }^{\circledR}$ was the first photosensitizer approved for human use, and has been successfully employed in the preatment of many types of tumor, including lung, esophageal, cervical, bladder and gastric tumors [2-4]. To enhance the potential of PDT and its clinical applications, a second generation of photosensitizers was produced, with properties comparable or superior to Photofrin ${ }^{\circledR}$, including chemical purity, increased photon absorption at longer wavelengths, improved tumor tissue retention, rapid clearance from surrounding normal tissue, high quantum yield of reactive oxygen species, and minimal toxicity in the dark [3,5-7]. The development of new sensitizers, the acquired knowledge on the conditions related with selective photosensitizer accumulation in target tissues and the improvement in the systems used for light delivery led to the development of PDT for use against ophthalmological, cardiovascular and immune-mediated conditions $[3,4,8,9]$. In addition to the development of new photosensitizers, the improvement of clinical PDT will rely on the translation of information generated from studies concerning the basic mechanisms involved in the demise process in photosensitized cells. This review focuses on recent advances in understanding the role of the intracellular 
signaling machinery in apoptotic death in PDT. Understanding the signaling mechanisms in PDT may provide means to modulate the PDT effects at the molecular level.

\section{Mechanisms of cell death in PDT}

The anti-cancer effects of PDT are thought to occur at two different levels: (i) direct lethal effects on tumor cells, and (ii) vascular impairment which limit blood supply to the region [2]. The interaction of light with the photosensitizer molecule raises its energy state and in the presence of molecular oxygen leads to the formation of reactive oxygen species, primarily singlet oxygen $\left({ }^{1} \mathrm{O}_{2}\right)$, which can react with electron rich regions of many biomolecules, giving rise to oxidized species $[2,10]$. Since singlet oxygen has a very short lifetime in cells, its intracellular targets are located close to the sites where the sensitizer is located [11]. Therefore, it is not surprising that the type of response triggered by activation of the photosensitizers depends on their intracellular localization [12-17]. The cell genotype and the PDT dose were also found to determine whether cell death occurs by apoptosis or necrosis [17-28]. Indeed, apoptosis was the predominant mode of cell death when murine leukemia P388 cells were photosensitized with chloroaluminum phthalocyanine (AlPc), using low light doses, whereas necrosis was observed for higher light doses [18]. Similar results were obtained in studies where human bladder carcinoma HT1197 cells were subjected to 5-aminolevulinate (ALA)-induced PDT [24] and in CNE2 cells, TWO-1 cells (human nasopharyngeal carcinoma cells) and AY-27 cells (chemically-induced rat bladder carcinoma cells) sensitized with hypericin [23,25]. These findings indicate that the type of cell death switches from apoptosis to necrosis with the increase of the intensity of the insult, as previously reported for other apoptotic stimuli [29].

\subsection{Apoptotic cell death in PDT}

Two major apoptotic pathways have been characterized: the death receptor-mediated, or extrinsic pathway, and the mitochondria-mediated apoptosis, or intrinsic pathway [3032]. In the first pathway, cell surface receptors from the tumor necrosis factor (TNF) gene family are stimulated, activating the initiator caspase- 8 via adaptor and scaffolding proteins [33]. The second process is triggered by disruption of mitochondrial function, which causes the release of cytochrome $C$ to the cytosol [34]. Released cytochrome $C$ binds Apaf-1 and induces its oligomerization, in the presence of dATP. This complex, termed apoptosome, recruits and activates the initiator caspase-9 [35-37].

In both pathways, the activation of initiator caspases (caspase-8 or caspase-9) leads to the activation of effector caspases (caspase-3, -6 and -7) (Fig. 1). During apoptosis the cells shrink, the nuclear chromatin becomes pyknotic and condenses against the nuclear membrane, and eventu- ally the cytoplasm and the nucleus break up into apoptotic bodies. Although the cytoplasmic organelles remain intact, DNA is digested at internucleosomal sites, giving rise to fragments that are multiples of $180-200$ bp [30-32]. Apoptotic cells and apoptotic bodies are engulfed and cleared by phagocytes [38].

\subsubsection{Death receptor-mediated apoptosis in PDT}

Photosensitization of human epidermoid carcinoma A431 cells with silicon phthalocyanine 4 ( $\mathrm{Pc} 4)$ transiently increased the protein levels of the surface death receptor Fas (also known as APO-1 or CD95) and of its ligand FasL, under conditions where cell death occurred by apoptosis [39]. Under the same conditions, a multimerization of the Fas protein and interaction of the receptor with the adaptor molecule FADD (Fas-associated protein with a death domain) were also observed [39]. The Fas-FADD complex is known to bind procaspase-8, and on this molecular scaffold, procaspase- 8 activates itself proteolytically and triggers the death pathway [30-33]. Accordingly, caspase-8 cleavage was observed in the human epidermoid carcinoma A431 cells sensitized with Pc 4, and pre-incubation of the cells with rhFas:Fc fusion protein partially inhibited cell death [39]. Antibodies against Fas or FasL also reduced apoptotic death of poorly differentiated CNE2 and of moderately differentiated TWO-1 human nasopharyngeal cells subjected to PDT with Hypocrellin A and Hypocrellin B [40]. In in vivo studies, in which NR-S1 tumor-bearing mice were treated by PDT with Photofrin ${ }^{\circledR}$, Fas-positive tumor cells were observed in the same area where many TUNELpositive tumor cells were found, and expression of Fas and FasL was also observed in the tumor cells surrounding TUNEL-positive cells [41]. The role of the Fas/FasL system in PDT may explain the cooperativity observed in MDCK II (2-8 Madison-Darby canine kidney cells) and V79 (Chinese hamster lung fibroblasts) cell death after photosensitization with Photofrin ${ }^{\circledR}$ [42]. Accordingly, MDCK cells were found to express Fas and FasL (e.g. see Ref. [43]).

Activation of caspase- 8 was found to mediate apoptotic death of human promyelocytic HL-60 cells photosensitized with Rose Bengal $[21,44]$. In this model, inhibition of caspase- 8 also prevented cytochrome $C$ release from mitochondria and cleavage of procaspase-3 [21], suggesting that caspase- 8 acts upstream of these events. Caspase- 8 is known to cleave $\mathrm{Bid}\left(\mathrm{BH}_{3}\right.$-interacting domain death agonist), generating a $\mathrm{C}$-terminal fragment of the protein, $\mathrm{tBid}$, that can activate the mitochondrial apoptotic pathway [45-47]. Bid seems to promote death by activating the pro-apoptotic proteins $\mathrm{Bax}$ and Bak, and it may also inactivate prosurvival proteins [45-47], thereby inducing the release of cytochrome $C$ (see below).

PDT with Rose Bengal increased p38 MAPK (mitogenactivated protein kinase) activity, and inhibition of the kinase prevented Bid cleavage, the decrease in mitochondrial membrane potential and the release of cytochrome $C$ from the mitochondria [44]. Since cleavage of procaspase- 8 was not 


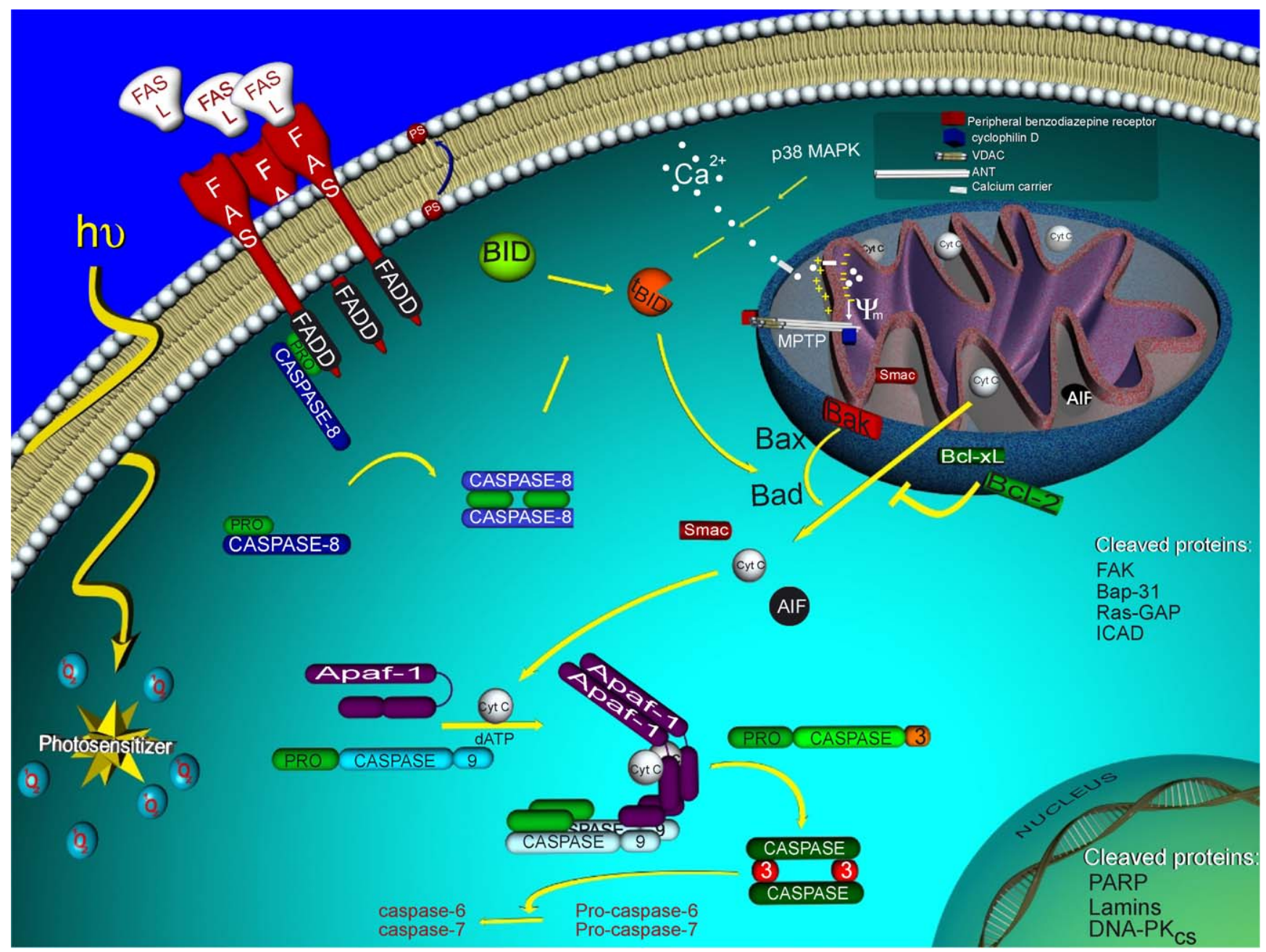

Fig. 1. Major molecular events leading to cell death in PDT-treated cells. The two major apoptotic pathways, the death receptor-mediated, or extrinsic pathway, and the mitochondria-mediated-pathway are represented. The diagram summarizes the results obtained in different tumor models using various sensitizers.

affected by the p38 MAPK inhibitor, it was suggested that caspase- 3 activation in this system is regulated through redundant signaling pathways that involve caspase- 8 and p38 MAPK acting upstream of Bid [44]. Although the fast kinetics of caspase-8 activation in HL-60 cells subjected to PDT with Rose Bengal may suggest that singlet oxygen generated during photoactivation of the sensitizer directly induces multimerization-mediated activation of the Fas receptor, even in the absence of the FasL [21], a rapid upregulation of the Fas and FasL protein levels was observed in human epidermoid carcinoma A431 cells sensitized with Pc 4 [39]. In contrast, a direct effect of the sensitizer on the activation of the Fas receptor is supported by studies showing that ultraviolet $\mathrm{A}$ radiation induces formation of the Fas-FADD-caspase-8 death complex in HL-60 cells in a FasL-independent manner [48]. Furthermore, immunoprecipitation studies showed multimerization of Fas without Fas ligand in normal human keratinocytes sensitized with 13,17bis(1-carboxypropionyl)carbamoylethyl-8-ethenyl-2-hydroxy-3-hydroxyiminoethylidene-2,7,12,18-tetramethylporphyrin (ATX-S10) [1]. Under these conditions, there was a release of cytochrome $C$ and apoptosis-inducing factor (AIF) from mitochondria and a decrease in the Bax protein levels in the cytosol [1].

Despite the evidences indicating a role for the death receptor-mediated mechanism in apoptotic death of PDTtreated cells, it was found that FADD null mouse embryonic fibroblasts still undergo apoptosis when photosensitized with Pc 4 [49]. These results indicate that in this case other mechanisms may be involved in apoptotic death in PDT.

\subsubsection{Mitochondria-mediated apoptosis in PDT}

Some sensitizers target mitochondria (e.g. see Refs. $[12,25,50-56]$, organelles that play a central role in apoptosis [57]). In this case, it is not surprising that PDT can induce apoptosis rapidly, both in vivo [41] and in vitro (e.g. see Ref. [58]; see Table 1 and other references throughout the manuscript). However, since photosensitizers may also be accumulated in other cellular compartments (e.g. lysosomes, endoplasmic reticulum (ER), Golgi apparatus), local damage induced by photo- 
Table 1

Major molecular events during apoptotic death induced by PDT

\begin{tabular}{|c|c|c|c|}
\hline Cellular event & Sensitizer & Cell line & References \\
\hline \multirow{18}{*}{$\begin{array}{l}\text { Cytochrome } C \text { release } \\
\text { from mitochondria }\end{array}$} & Aluminum phthalocyanine & Human breast epithelial cell line MCF10A & [94] \\
\hline & 5-Aminolevulinate (ALA) & Human promyelocytic leukemia HL60 cell line & {$[78]$} \\
\hline & \multirow[t]{2}{*}{$N$-aspartyl chlorin $\mathrm{e}_{6}$} & Mouse leukemia L1210 cells & {$[278]$} \\
\hline & & Murine hepatoma Hepa 1c1c7 & {$[60]$} \\
\hline & ATX-S10 & Normal human keratinocytes & {$[1]$} \\
\hline & \multirow{3}{*}{$\begin{array}{l}\text { Benzoporphyrin derivative monoacid } \\
\text { ring A (BPD-MA, verteporfin) } \\
\text { 9-capronyloxy-tetrakis (methoxyethyl) } \\
\text { porphycene (CPO) }\end{array}$} & Human adenocarcinoma HeLa cells & {$[71,73]$} \\
\hline & & Human umbilical venous endothelial cells & {$[72]$} \\
\hline & & Mouse leukemia L1210 cells & {$[59]$} \\
\hline & \multirow[t]{2}{*}{ Hypericin } & Human adenocarcinoma HeLa cells & {$[20]$} \\
\hline & & Rat/mouse $\mathrm{T}$ cell hybridoma & {$[68]$} \\
\hline & $\begin{array}{l}\text { Meta-tetra(hydroxyphenyl)-chlorin } \\
\left.\text { (mTHPC; Foscan }{ }^{\circledR}\right)\end{array}$ & Human breast adenocarcinoma MCF-7 cells & {$[61]$} \\
\hline & \multirow[t]{4}{*}{ Silicon phthalocyanine 4 (Pc 4) } & Human epidermoid carcinoma A431 cells & {$[54]$} \\
\hline & & L5178Y-R mouse lymphoma & {$[64,70]$} \\
\hline & & Jurkat human lymphoma T cells & {$[85]$} \\
\hline & & Human breast adenocarcinoma MCF-7c 3 cells & {$[88,99,100]$} \\
\hline & Pheophorbide $a$ & Chinese hamster V79 cells & {$[63]$} \\
\hline & Porphycene monomer (PcM) & Murine leukemia P388 cells & {$[67]$} \\
\hline & Rose Bengal & Human promyelocytic leukemia HL60 cell line & {$[44]$} \\
\hline \multirow{18}{*}{$\begin{array}{l}\text { Loss of mitochondrial } \\
\text { membrane potential }\end{array}$} & Aluminum phthalocyanine & Human breast epithelial cell line MCF10A & [94] \\
\hline & \multirow[t]{2}{*}{ 5-Aminolevulinate (ALA) } & Human promyelocytic leukemia HL60 cell line & {$[78]$} \\
\hline & & $\begin{array}{l}\text { Human breast cancer MCF-7 cells and } \\
\text { adriamycin-resistant MCF-7/ADR cells }\end{array}$ & {$[28]$} \\
\hline & $N$-aspartyl chlorin $\mathrm{e}_{6}$ & Murine hepatoma Hepa 1c1c7 & {$[60]$} \\
\hline & $\begin{array}{l}\text { 9-Capronyloxy-tetrakis } \\
\text { (methoxyethyl) porphycene (CPO) }\end{array}$ & Mouse leukemia L1210 cells & {$[59]$} \\
\hline & $\begin{array}{l}13,15-N \text {-cycloimide derivatives of } 13 \text {, } \\
15-[N-(3 \text {-hydroxypropyl) }] \text { cycloimide } \\
\text { chlorin p6 }\end{array}$ & Human lung adenocarcinoma A549 cells & {$[17]$} \\
\hline & $\begin{array}{l}\text { 5,10-di[4-( } N \text {-trimethylaminophenyl)-15, } \\
\text { 20-diphenylporphyrin (DADP-a) }\end{array}$ & Mouse leukemia L1210 cells & {$[16]$} \\
\hline & Hematoporphyrin & Human chronic myelogenous leukemia K562 cells & {$[65]$} \\
\hline & \multirow[t]{3}{*}{ Hypericin } & $\begin{array}{l}\text { J Jhan cells (derived from human } \\
\text { lymphoblastoid Jurkat cells) }\end{array}$ & {$[69]$} \\
\hline & & Human glioblastoma SNB-19 cell line & {$[256]$} \\
\hline & & Rat/mouse T cell hybridoma (PC60R1R2) & {$[68]$} \\
\hline & $\begin{array}{l}\text { Meta-tetra(hydroxyphenyl)-chlorin } \\
\left.\text { (mTHPC; Foscan }{ }^{\circledR}\right)\end{array}$ & Human breast adenocarcinoma MCF-7 cells & {$[61]$} \\
\hline & Monoglucosylporphyrin & Human chronic myelogenous leukemia K562 cells & {$[65]$} \\
\hline & \multirow[t]{2}{*}{ Silicon phthalocyanine 4 (Pc 4) } & Human epidermoid carcinoma A431 cells & {$[54]$} \\
\hline & & Jurkat human lymphoma T cells & {$[161]$} \\
\hline & Porphycene monomer (PcM) & Murine leukemia P388 cells & {$[67]$} \\
\hline & Rose Bengal & Human promyelocytic leukemia HL60 cell line & {$[44]$} \\
\hline & $\begin{array}{l}\text { Tetrasulfonated aluminum (III) } \\
\text { phthalocanine }\left(\mathrm{AlPcS}_{4}\right)\end{array}$ & Human epidermoid carcinoma A431 cells & {$[66]$} \\
\hline \multirow{8}{*}{$\begin{array}{l}\text { Cleavage of pro-caspase- } 9 \\
\text { /caspase- } 9 \text { formation }\end{array}$} & 5-Aminolevulinate (ALA) & Human promyelocytic leukemia HL60 cell line & {$[78]$} \\
\hline & $N$-aspartyl chlorin $\mathrm{e}_{6}$ & Murine hepatoma Hepa 1c1c7 & {$[60]$} \\
\hline & \multirow{3}{*}{$\begin{array}{l}\text { Benzoporphyrin derivative monoacid } \\
\text { ring A (BPD-MA, verteporfin) }\end{array}$} & Human adenocarcinoma HeLa cells & {$[73]$} \\
\hline & & Human promyelocytic leukemia HL60 cell line & {$[79]$} \\
\hline & & Human umbilical venous endothelial cells & {$[72]$} \\
\hline & $\begin{array}{l}\text { Bisulfonated aluminum } \\
\text { phthalocyanine }\left(\mathrm{AlPcS}_{2}\right)\end{array}$ & Human promyelocytic leukemia HL60 cell line & {$[183]$} \\
\hline & \multirow[t]{2}{*}{ Silicon phthalocyanine $4(\operatorname{Pc} 4)$} & $\begin{array}{l}\text { SW480 colon cancer xenographs grown in } \\
\text { athymic nude mice }\end{array}$ & {$[231]$} \\
\hline & & Human breast adenocarcinoma MCF-7c3 cells & {$[88]$} \\
\hline \multirow{5}{*}{$\begin{array}{l}\text { Cleavage of pro-caspase- } 3 \\
\text { /caspase- } 3 \text { formation }\end{array}$} & 5-Aminolevulinate (ALA) & Human promyelocytic leukemia HL60 cell line & {$[78]$} \\
\hline & \multirow{4}{*}{$\begin{array}{l}\text { Benzoporphyrin derivative monoacid } \\
\text { ring A (BPD-MA, verteporfin) }\end{array}$} & Human promyelocytic leukemia HL60 cell line & {$[75,76,79]$} \\
\hline & & Human umbilical venous endothelial cells & {$[72]$} \\
\hline & & Human promyelocytic leukemia HL60 cell line & {$[77,79]$} \\
\hline & & Human adenocarcinoma HeLa cells & {$[71,73]$} \\
\hline
\end{tabular}


Table 1 (continued)

\begin{tabular}{|c|c|c|c|}
\hline Cellular event & Sensitizer & Cell line & References \\
\hline \multirow[t]{8}{*}{$\begin{array}{l}\text { Cleavage of pro-caspase- } 3 \\
\text { /caspase- } 3 \text { formation }\end{array}$} & $\begin{array}{l}\text { Bisulfonated aluminum } \\
\text { phthalocyanine }\left(\mathrm{AlPcS}_{2}\right)\end{array}$ & Human promyelocytic leukemia HL60 cell line & {$[183]$} \\
\hline & Hypericin & Rat/mouse T cell hybridoma (PC60R1R2) & {$[68]$} \\
\hline & & $\begin{array}{l}\text { Human transitional cell carcinoma of the } \\
\text { urinary bladder (T24) }\end{array}$ & {$[145]$} \\
\hline & & Human adenocarcinoma HeLa cells & {$[20]$} \\
\hline & QLT0074 & Jurkat human lymphoma T cells & {$[26]$} \\
\hline & Silicon phthalocyanine 4 (Pc 4) & $\begin{array}{l}\text { SW } 480 \text { colon cancer xenographs grown } \\
\text { in athymic nude mice }\end{array}$ & {$[231]$} \\
\hline & & Human breast adenocarcinoma MCF-7c3 cells & {$[88]$} \\
\hline & Rose Bengal & Human promyelocytic leukemia HL60 cell line & {$[44]$} \\
\hline \multirow{3}{*}{$\begin{array}{l}\text { Cleavage of pro-caspase- } 6 \\
\text { /caspase- } 6 \text { formation }\end{array}$} & Benzoporphyrin derivative monoacid & Human promyelocytic leukemia HL60 cell line & {$[77]$} \\
\hline & ring A (BPD-MA, verteporfin) & Human umbilical venous endothelial cells & {$[72]$} \\
\hline & & Human adenocarcinoma HeLa cells & {$[71,73]$} \\
\hline \multirow{2}{*}{$\begin{array}{l}\text { Cleavage of pro-caspase- } 7 \\
\text { /caspase- } 7 \text { formation }\end{array}$} & Benzoporphyrin derivative monoacid & Human umbilical venous endothelial cells & {$[72]$} \\
\hline & ring A (BPD-MA, verteporfin) & Human adenocarcinoma HeLa cells & {$[71,73]$} \\
\hline \multirow{4}{*}{$\begin{array}{l}\text { Cleavage of pro-caspase- } 8 \\
\text { /caspase- } 8 \text { formation }\end{array}$} & Benzoporphyrin derivative monoacid & Primary human umbilical venous endothelial cells & {$[72]$} \\
\hline & ring A (BPD-MA, verteporfin) & Human adenocarcinoma HeLa cells & {$[71,73]$} \\
\hline & Silicon phthalocyanine 4 (Pc 4) & Human epidermoid carcinoma A431 cells & [39] \\
\hline & Rose Bengal & Human promyelocytic leukemia HL60 cell line & {$[21,44]$} \\
\hline \multirow[t]{8}{*}{ Annexin $\mathrm{V}$ binding } & 5-Aminolevulinate (ALA) & Cultured human cervical C33-A cells & {$[279]$} \\
\hline & Hypericin & $\begin{array}{l}\text { J Jhan cells (derived from human } \\
\text { lymphoblastoid Jurkat cells) }\end{array}$ & {$[69]$} \\
\hline & & Human glioblastoma SNB-19 cell line & {$[256]$} \\
\hline & & $\begin{array}{l}\text { Poorly (CNE2) and moderately (TWO-1) } \\
\text { differentiated human nasopharyngeal carcinoma cells }\end{array}$ & {$[25]$} \\
\hline & Hypocrellin A and B & $\begin{array}{l}\text { Poorly (CNE2) and moderately (TWO-1) } \\
\text { differentiated human nasopharyngeal carcinoma cells }\end{array}$ & {$[25]$} \\
\hline & QLT0074 & Jurkat human lymphoma T cells & {$[26]$} \\
\hline & Silicon phthalocyanine 4 (Pc 4) & $\begin{array}{l}\text { Radiation-induced fibrosarcoma (RIF-1) } \\
\text { tumors grown in } \mathrm{C} 3 \mathrm{H} \text { mice }\end{array}$ & {$[280]$} \\
\hline & $\begin{array}{l}\text { Tetrasulfonated aluminum (III) } \\
\text { phthalocanine }\left(\mathrm{AlPcS}_{4}\right)\end{array}$ & Rat bladder RR1022 epithelial cells & {$[113]$} \\
\hline \multirow[t]{25}{*}{ PARP cleavage } & 5-Aminolevulinate (ALA) & Human promyelocytic leukemia HL60 cell line & {$[78]$} \\
\hline & & Human adenocarcinoma HeLa cells & {$[71,73]$} \\
\hline & Benzoporphyrin derivative monoacid & Human promyelocytic leukemia HL60 cell line & {$[75-77,79]$} \\
\hline & ring A (BPD-MA, verteporfin) & Human umbilical venous endothelial cells & {$[72]$} \\
\hline & Chloroaluminum phthalocyanine & Murine leukemia P388 cells & {$[18]$} \\
\hline & Hypericin & Human adenocarcinoma HeLa cells & {$[20,80,81]$} \\
\hline & & $\begin{array}{l}\text { Human transitional cell carcinoma of the } \\
\text { urinary bladder }(\mathrm{T} 24)\end{array}$ & {$[145]$} \\
\hline & & Rat/mouse T cell hybridoma (PC60R1R2) & {$[68]$} \\
\hline & Hypocrellin A and B & $\begin{array}{l}\text { Poorly (CNE2) and moderately (TWO-1) } \\
\text { differentiated human nasopharyngeal carcinoma cells }\end{array}$ & {$[25]$} \\
\hline & Pheophorbide $a$ & Colon tumor HT29 cells & {$[265]$} \\
\hline & Photofrin ${ }^{\circledR}$ & Colon tumor HT29 cells & {$[265]$} \\
\hline & QLT0074 & Jurkat human lymphoma T cells & {$[26]$} \\
\hline & Rose Bengal & Human promyelocytic leukemia HL60 cell line & {$[44]$} \\
\hline & Silicon phthalocyanine 4 (Pc 4) & Murine lymphoma L5178Y-R & {$[83]$} \\
\hline & & Human epidermoid carcinoma A431 cells & {$[261]$} \\
\hline & & Chemically-induced murine skin papillomas & {$[261]$} \\
\hline & & RIF-1 cells treated with Bcl-2 antisense oligonucleotide & {$[93]$} \\
\hline & & Human epidermoid carcinoma A431 cells & {$[54,82]$} \\
\hline & & LNCaP cells & [84] \\
\hline & & Jurkat human lymphoma T cells & {$[85]$} \\
\hline & & $\begin{array}{l}\text { SW } 480 \text { colon cancer xenographs } \\
\text { grown in athymic nude mice }\end{array}$ & {$[231]$} \\
\hline & & Chemically induced skin papilloma in SENCAR mice & {$[82]$} \\
\hline & & $\begin{array}{l}\text { UV radiation-induced skin tumors in SKH-1 } \\
\text { hairless mice }\end{array}$ & {$[82]$} \\
\hline & & Human breast cancer MCF-7c3 cells & {$[88]$} \\
\hline & & $\begin{array}{l}\text { Ovarian epithelial carcinoma (OVCAR-3)-bearing } \\
\text { athymic nude mice }\end{array}$ & {$[230]$} \\
\hline
\end{tabular}


Table 1 (continued)

\begin{tabular}{|c|c|c|c|}
\hline Cellular event & Sensitizer & Cell line & References \\
\hline \multirow[t]{50}{*}{ DNA fragmentation } & \multirow[t]{4}{*}{ 5-Aminolevulinate (ALA) } & Human promyelocytic leukemia HL60 cell line & [78] \\
\hline & & V79 Chinese hamster lung fibroblast cell line & {$[281]$} \\
\hline & & CDF1 mice bearing the colon- 26 tumor & {$[282]$} \\
\hline & & Intracranially-implanted VX2 carcinoma & {$[283]$} \\
\hline & $N$-aspartyl chlorin $\mathrm{e}_{6}$ & Mouse leukemia L1210 cells & [278] \\
\hline & \multirow{2}{*}{$\begin{array}{l}\text { Benzoporphyrin derivative monoacid } \\
\text { ring A (BPD-MA, verteporfin) }\end{array}$} & Murine P815 mastocytoma cells & [198] \\
\hline & & Human promyelocytic leukemia HL60 cell line & {$[76]$} \\
\hline & $\begin{array}{l}\text { Bisulfonated aluminum } \\
\text { phthalocyanine }\left(\mathrm{AlPcS}_{2}\right)\end{array}$ & Human promyelocytic leukemia HL60 cell line & [183] \\
\hline & $\begin{array}{l}\text { 2-Butylamino-2-demethoxyhypocrellin } \\
\text { A (2-BA-2-DMHA) }\end{array}$ & Human gastric adenocarcinoma MGC803 cells & {$[92]$} \\
\hline & Chloroaluminum phthalocyanine & Mouse lymphoma L5178Y cells & {$[284]$} \\
\hline & $\begin{array}{l}\text { Chloroaluminum phthalocyanine } \\
\text { tetrasulfonate }\end{array}$ & RIF-1 tumor-bearing $\mathrm{C} 3 \mathrm{H} / \mathrm{HeN}$ mice & {$[285]$} \\
\hline & DO15 (methylene blue analog) & Mouse leukemia P388 cells & {$[286]$} \\
\hline & Hematoporphyrin & $\begin{array}{l}\text { Human chronic myelogenous } \\
\text { leukemia K562 cells }\end{array}$ & {$[65]$} \\
\hline & \multirow[t]{2}{*}{ Hematoporphyrin derivative (HPD) } & Human liver adenocarcinoma SKHEP-1 cells & [287] \\
\hline & & Murine fibroblasts, clone L929 & [109] \\
\hline & Hypericin & Human adenocarcinoma HeLa cells & {$[20]$} \\
\hline & Lutetium texaphyrin (PCI-0123) & EMT6 sarcoma-bearing BALB/c mice & {$[288]$} \\
\hline & Merocyanine 540 & Murine myeloid leukemia JCS cell line & [289] \\
\hline & Meta-tetra(hydroxyphenyl)-chlorin & Murine myeloid leukemia JCS cell line & [289] \\
\hline & \multirow{2}{*}{$\left(\mathrm{mTHPC} ;\right.$ Foscan ${ }^{\circledR}$ ) } & Intracranially implanted VX2 carcinoma & [283] \\
\hline & & Murine myeloid leukemia M1 cell line & [289] \\
\hline & $\begin{array}{l}\text { Mesochlorin } \mathrm{e}_{6} \text { monoethylenediamine } \\
\text { (Mce })_{6} \text {, and } \\
N \text {-(2-hydroxypropyl)methacrylamide } \\
\text { (HPMA) copolymer-Mce conjugates }\end{array}$ & Human ovarian carcinoma A2780 cells & {$[15]$} \\
\hline & Monoglucosylporphyrin & $\begin{array}{l}\text { Human chronic myelogenous } \\
\text { leukemia K562 cells }\end{array}$ & {$[65]$} \\
\hline & \multirow[t]{3}{*}{ Pheophorbide $a$} & Chinese hamster V79 cells & [63] \\
\hline & & Human pancreatic tumor cell line (HA-hpc2) & [22] \\
\hline & & Colon tumor HT29 cells & [265] \\
\hline & \multirow[t]{5}{*}{ Photofrin ${ }^{\circledR}$} & HL-60 derived cell line & [291] \\
\hline & & $\begin{array}{l}\text { Human pancreatic carcinoma } \\
\text { transplanted into nude mice }\end{array}$ & [292] \\
\hline & & V79 Chinese hamster lung fibroblasts & [14] \\
\hline & & Colon tumor HT29 cells & {$[265]$} \\
\hline & & Intracranially implanted VX2 carcinoma & {$[283]$} \\
\hline & \multirow[t]{6}{*}{ Photofrin II } & Human prostate carcinoma PC3 cells & [293] \\
\hline & & Human non-small cell lung carcinoma (H322a) & [293] \\
\hline & & Rat mammary carcinoma MTF7 cells & [293] \\
\hline & & RIF-1 tumor-bearing $\mathrm{C} 3 \mathrm{H} / \mathrm{HeN}$ mice & {$[285]$} \\
\hline & & Human adenocarcinoma HeLa cells & {$[255]$} \\
\hline & & Human cervical cancer CaSki cell lines & {$[255]$} \\
\hline & Porphycene dimmer (PcD) & Mouse leukemia P388 cells & {$[13]$} \\
\hline & Rose Bengal & Human promyelocytic leukemia HL60 cell line & {$[44,294]$} \\
\hline & \multirow[t]{11}{*}{ Silicon phthalocyanine 4 (Pc 4) } & $\begin{array}{l}\text { Chinese hamster ovary }(\mathrm{CHO}) \\
\text { cell-derived cell line }\end{array}$ & [91] \\
\hline & & $\begin{array}{l}\text { RIF-1 cells treated with Bcl-2 } \\
\text { antisense oligonucleotide }\end{array}$ & [93] \\
\hline & & Human epidermoid carcinoma A431 cells & [229] \\
\hline & & Human breast adenocarcinoma MCF- $7 \mathrm{c} 3$ cells & {$[88]$} \\
\hline & & Chinese hamster ovary $(\mathrm{CHO})$ cells & {$[155,193]$} \\
\hline & & Murine lymphoma L5178Y-R cells & $\begin{array}{l}{[83,120,154,} \\
155,193,197]\end{array}$ \\
\hline & & Human prostate tumor $\mathrm{LNCaP}$ cells & [84] \\
\hline & & Human leukemia U937 cells & [155] \\
\hline & & Promonocytic U1 cells & [19] \\
\hline & & $\begin{array}{l}\text { SENCAR mice bearing chemically } \\
\text { induced squamous papillomas }\end{array}$ & [290] \\
\hline & & RIF-1 tumor-bearing $\mathrm{C} 3 \mathrm{H} / \mathrm{HeN}$ mice & {$[285]$} \\
\hline
\end{tabular}


Table 1 (continued)

\begin{tabular}{|c|c|c|c|}
\hline Cellular event & Sensitizer & Cell line & References \\
\hline \multirow[t]{7}{*}{ DNA fragmentation } & Silicon phthalocyanine 4 (Pc 4) & $\begin{array}{l}\text { Ovarian epithelial carcinoma } \\
\text { (OVCAR-3)-bearing athymic nude mice }\end{array}$ & {$[230]$} \\
\hline & $\begin{array}{l}\text { Sulfonated meso-tetraphenylporphine } \\
\left(\mathrm{TPPS}_{4} \text { and } \mathrm{TPPS}_{2 \mathrm{a}}\right)\end{array}$ & V79 Chinese hamster lung fibroblasts & {$[14]$} \\
\hline & Tetra(3-hydroxyphenyl)porphyrin & V79 Chinese hamster lung fibroblasts & [14] \\
\hline & Tin ethyl etiopurpurin (SnET2) & HL-60 derived cell line & [291] \\
\hline & & Intracranially implanted VX2 carcinoma & [283] \\
\hline & & Mouse leukemia P388 cells & [13] \\
\hline & Toluidine blue & Jurkat human lymphoma T cells & [295] \\
\hline
\end{tabular}

sensitization may be propagated to the mitochondria by various means (e.g. see Refs. [12-17,59-62]).

Studies using different cell models and various sensitizers have shown that photosensitization induces a rapid release of cytochrome $C$ from the mitochondria (Table 1). The intracellular $\mathrm{Ca}^{2+}$ chelator BAPTA inhibited PDTinduced cytochrome $C$ release and caspase- 3 activation in photosensitized Chinese hamster V79 cells, suggesting that the increase in the intracellular $\mathrm{Ca}^{2+}$ levels may be a trigger for cytochrome $C$ release from mitochondria [63]. In L5178Y-R mouse lymphoma (LY-R) cells subjected to PDT with the Pc 4, the rapid release of a fraction of the mitochondrial cytochrome $C$ was followed by a partial inhibition of respiration [64]. A drop in mitochondrial membrane potential, concurrent with a drop in ATP levels and a decrease in cell respiration, was also observed in the early phase of the response of promyelocytic K562 cells to photodynamic treatment with hematoporphyrin or with monoglucosylporphyrin [65]. Studies using human epidermoid carcinoma A431 cells suggested that PDT causes an up-regulation of glycolytic phosphorylation as a compensatory mechanism to overcome mitochondrial disfunction and to provide energy equivalents required for apoptotic cell death [66]. Indeed, glycolytic ATP production constitutes a strict obligation during the initial events of the demise process [66].

\subsubsection{Role of caspases in PDT. A broad spectrum} caspase inhibitor (z-VAD-FMK) did not prevent the loss of mitochondrial membrane potential in murine leukemia P388 cells subjected to PDT with porphycene monomer [67], and in rat/mouse T cell hybridoma PC60R1R2 cells sensitized with hypericin [68], indicating that the early events occurring at the mitochondria are upstream of caspase activation. Also, inhibition of caspase-3-like activity with Ac-DEVD-CHO did not affect mitochondrial depolarization in human epidermoid carcinoma A431 cells subjected to PDT with Pc 4 [54]. In this system, cyclosporin A plus trifluoroperazine, blockers of the mitochondrial permeability transition, inhibited mitochondrial inner membrane permeabilization and depolarization, and the release of cytochrome $C$ [54]. In contrast, cyclosporin A was without effect on the loss of mitochondrial membrane potential and on cytochrome $C$ release in rat/mouse hybrid- oma PC60R1R2 cells sensitized with hypericin [68], indicating that in this case the opening of the pore is not the causative mechanism of dissipation of the potential. Preincubation of Jurkat cells with inhibitors of the mitochondrial permeability transition pore was also without effect on the loss of mitochondrial membrane potential induced by PDT with hypericin [69]. Interestingly, in mouse L5178Y-R cells exposed to low doses of PDT, cytochrome $C$ was released from mitochondria without loss of mitochondrial membrane potential, suggesting that the release of cytochrome $C$ is independent of the loss of mitochondrial membrane potential [70]. Photosensitization of hepatoma Hepa 1c1c7 cells with the lysosomal sensitizer Npe6 also induced the release of cytochrome $C$ and activated caspase9 and caspase-3-like activity before depolarization of the mitochondrial membrane [60]. It was proposed that these sensitizers may disrupt lysosomes, releasing protease(s) into the cytosol which may convert Bid into a truncated form (tBid). In this case, tBid would trigger the release of cytochrome $C$, thereby activating Apaf-1/pro-caspase-9 [60].

The release of cytochrome $C$ to the cytosol in photosensitized cells induces the cleavage of the initiator caspase-9, followed by cleavage (activation) of several other caspases, including caspase- $2,-3,-6,-7$ and -8 , in several cell types (see Table 1). Although cleavage of caspase8 typically occurs prior to cytochrome $C$ release from mitochondria in death receptor-mediated apoptosis (see above), in some cases of PDT-induced apoptosis caspase8 activation followed cytochrome $C$ release, and most likely is secondary to activation of caspase-3 [71-73]. This activation of caspase- 8 may amplify cytochrome $C$ release by cleavage of Bid into a truncated form (tBid), which is known to cause cytochrome $C$ release from mitochondria $[71,72,74]$. Cleavage of procaspase- 8 in human adenocarcinoma HeLa cells sensitized with benzoporphyrin derivative monoacid ring A (BPD-MA; verteporfin) followed cleavage of caspase- $3,-6$ and -7 , indicating that activation of caspase- 8 is not an early event in some models of PDT [71]. However, expression of the caspase-1 and caspase8 inhibitor CrmA (viral cytokine response modifier A) did not affect apoptotic death of human adenocarcinoma HeLa cells sensitized with hypericin [20]. Also, expression of CrmA did not affect the kinetics of cytochrome $C$ release 
and procaspase-3 cleavage in a rat/mouse $\mathrm{T}$ cell hybridoma sensitized with hypericin [68], suggesting that caspase8 does not play a major role in the demise process in this model.

The activation of caspases in photosensitized cells leads to the cleavage of a number of other cell proteins, including Bap-31 (shuttle protein between the ER and the intermediate compartment and/or Golgi complex [71]), DNA-dependent protein kinase (catalytic subunit) (DNA-PK ${ }_{\mathrm{CS}}$ [75]), ICAD (inhibitor of caspase activated DNAse); prevents DNA fragmentation via binding to caspase-activated deoxyribonuclease [76]), focal adhesion kinase (FAK, a kinase involved in the regulation of cell adhesion [73]), lamins (structural components of the nuclear envelope [73]), PARP (poly(ADP-ribose) polymerase, a DNA repair enzyme $[18,20,44,54,68,71,72,75,77-85])$ and Ras GTPase-activating protein (Ras-GAP, a negative regulator of the Ras signaling pathway [71]). DNA fragmentation in segments that are multiples of 180-200 bp, another hallmark of apoptotic cell death [86], was also observed in PDT, using different cell types and sensitizers (Table 1).

In contrast to the numerous reports showing the role of caspase-3-like enzymes in apoptotic death in photosensitized cells, a recent study where human cervix carcinoma HeLa cells were photosensitized with 2,4,5,7-tetrabromorhodamine 123 bromide (TBR), which is incorporated into the Golgi apparatus, showed that cell death occurred by a $\mathrm{Ca}^{2+}$-dependent and caspase-3-independent mechanism [87]. Despite the fact that no cleavage of procaspase-3 was observed, the morphology of sensitized cells showed condensed nuclear chromatin and apoptotic bodies, characteristic of cell death by apoptosis [87].

The role of caspase-3 in PDT was further investigated by comparing the response of caspase- 3 deficient cell line MCF-7 with MCF-7c3 cells, which express a stably transfected caspase-3 gene. Although MCF-7 cells were less sensitive to photosensitization with Pc 4 when compared with MCF-7c3 cells, as assayed by reduction of a tetrazolium salt, the two cell lines were equally sensitive to Pc 4PDT when evaluated by the clonogenic assay [88]. These results indicate that the critical step in Pc 4-PDT induced cell death is independent of caspase-3. Although cytochrome $C$ release following photosensitization was similar in both cell lines, there was a marked reduction in caspase-9 activation in MCF-7 cells, suggesting that caspase- 3 may be important for the amplification of the pro-caspase- 9 processing [88]. In vivo studies, in which xenographs of caspase-3-expressing (MCF-7c3) or deficient (MCF-7 and MCF-7v) cells were generated in athymic nude mice, showed that the final outcome of the Pc 4-PDT treatment was independent of the presence of the caspase [89].

2.1.2.2. Role of the Bcl-2 family of proteins in PDT. The Bcl-2 family of proteins can be subdivided in two groups based on their role in apoptotic cell death: Bcl-2, Bcl- $\mathrm{x}_{\mathrm{L}}$, Bcl-w, Mcl-1 and A1 possess anti-apoptotic activity, where- as Bax, Bak, Bok, Bid, Bim, Bik/Nbk, Bad, Bcl- $\mathrm{x}_{\mathrm{S}}, \mathrm{Bmf}$, Hrk, Noxa and Puma are pro-apoptotic (for reviews see Refs. [45-47]; see also Ref. [90]). Although the role of some of these proteins in PDT remains to be investigated, conflicting data have been obtained concerning the influence of Bcl-2 on the demise process in photosensitized cells.

Overexpression of Bcl-2 in the Chinese hamster ovary cell line CHO inhibited DNA fragmentation and apoptosis, and partly protected the cells from cell death, as determined by the clonogenic assay, in experiments where Pc 4 was used as a sensitizer [91]. Similar results were obtained using human acute myelogenous leukaemia HL-60 cells, with benzoporphyrin derivative monoacid ring A (BPD-MA) as a sensitizer and at low PDT doses [77]. In this case, Bcl-2 overexpression prevented pro-caspase- 3 and -6 cleavage, proteolysis of PARP and formation of hypodiploid DNA [77]. Overexpression of $\mathrm{Bcl}-\mathrm{x}_{\mathrm{L}}$ in HL-60 cells also prevented PDT-induced cleavage of pro-caspase-3 and DNA fragmentation [76]. Enforced expression of Bcl-2 also delayed PDT-induced apoptotic death in a rat/mouse $\mathrm{T}$ cell hybridoma (PC60R1R2) sensitized with hypericin, by delaying cytochrome $C$ release, pro-caspase-3 activation and PARP cleavage [68], and similar findings were reported in Jurkat cells photosensitized with hypericin [69]. This delay in apoptosis may be due to phosphorylation of Bcl-2, through a cyclin-dependent protein kinase 1 (CDK1)-dependent mechanism, which produces a delay of the $G_{2} / M$ phase, as proposed for human adenocarcinoma HeLa cells subjected to PDT with hypericin [81]. Overexpression of Bcl-2 and Bcl- $\mathrm{x}_{\mathrm{L}}$ also delayed morphological changes, depressed caspase activation, and limited substrate degradation in HeLa cells subjected to PDT with verteporfin, but no protection against loss of viability was observed [73]. In this case, overexpressing Bcl-2 or Bcl- $\mathrm{x}_{\mathrm{L}}$ did not affect cytochrome $C$ release from mitochondria following photosensitization, indicating that these proteins confer resistance to caspase-3 activation, even after the appearance of cytochrome $C$ in the cytosol [73].

The regulatory role of $\mathrm{Bcl}-2$ in PDT has also been investigated by transfecting an antisense Bcl-2 sequence in a retrovirus vector into a human gastric adenocarcinoma MGC803 cell line, followed by PDT with 2-BA-2-DMHA (2-butylamino-2-demethoxy-hypocrellin A [92]). Reduction of the Bcl-2 protein levels increased phototoxicity, as determined by the MTT assay and by the generation of oligonucleosomal DNA fragments [92]. Similarly, incubation of the PDT-resistant cell line RIF-1 (radiation-induced fibrosarcoma cells) with Bcl-2 antisense oligonucleotide resulted in sensitization to PDT-mediated apoptotic death, when the Pc 4 photosensitizer was used [93].

In contrast with the reports indicating that $\mathrm{Bcl}-2$ confers a certain degree of resistance to apoptotic death after PDT, studies using the MCF10A human breast epithelial cell line and the photosensitizer AlPc showed that overexpression of Bcl-2 increased PDT-induced apoptotic cell death [94]. This increase in the susceptibility to PDT was 
attributed to the observed up-regulation of Bax protein levels in transfected cells and to the selective degradation of $\mathrm{Bcl}-2$ in photosensitized cells [94]. A down-regulation of Bcl-2 protein levels in PDT-treated cells may have freed Bax to exert it pro-apoptotic effects, since the amount of this protein in the cell was not changed [94]. Bax is a cytosolic monomeric protein in healthy cells, but it changes conformation during apoptosis, integrates into the outer mitochondrial membrane and oligomerizes. These oligomers are thought to induce or contribute to the permeabilization of the outer mitochondrial membrane, allowing the efflux of apoptogenic proteins [45-47]. However, a recent study showed that the disappearance of Bcl-2 from Western Blots prepared from DU-145 cells photosensitized with the Pc 4 was instead due cross-link formation [55]. In this case Bax was not cross-linked by Pc 4-PDT [55], suggesting that the increase in sensitivity to PDT observed in Bcl-2 overexpressing cells may be due to a change in the balance of functional pro- and antiapoptotic members of the $\mathrm{Bcl}-2$ family of proteins. It remains to be determined whether photodamaged Bcl-2 retains its anti-apoptotic function.

Assuming that the function of Bcl-2 is lost when the high molecular weight complexes are formed, a change in the balance between the activity of pro- and anti-apoptotic proteins of the Bcl-2 family may also explain the enhanced sensitivity to PDT observed in human epidermoid carcinoma (A431) cells overexpressing Bcl-2 [93]. Photosensitization of these cells with Pc 4 reduced the protein levels of anti-apoptotic Bcl-2 and Bcl- $\mathrm{x}_{\mathrm{L}}$, as determined by Western Blot, and up-regulated protein expression of the pro-apoptotic Bcl- $\mathrm{x}_{\mathrm{S}}$, Bak and Bad, but not of Bid [93,95]. PDT of RIF-1 cells treated with a Bcl-2 antisense oligonucleotide also up-regulated the protein levels of Bcl- $\mathrm{x}_{\mathrm{s}}$, Bak and Bad, in addition to Bid [93]. Photosensitization of murine leukemia L1210 cells with various sensitizers reduced Bcl-2 protein levels, without affecting Bax $[59,96]$, as detected by Western Blot, and similar findings were reported for human breast cancer MCF-7 cells and DU-145 cells (human prostate cancer) sensitized with Pc $4[55,95,97]$. In the latter study, the protein levels of Bad were unchanged by PDT [97].

Taken together, the available evidences indicate that a shift in the balance between the activity of pro- and antiapoptotic members of the Bcl-2 family of proteins may decide the susceptibility of cells to PDT-mediated apoptotic death. However, this model contrasts with the lack of effect of PDT on Bcl-2 protein levels in studies using a rat/mouse $\mathrm{T}$ cell hybridoma (PC60R1R2) or human adenocarcinoma HeLa cells and the sensitizer hypericin $[68,81]$.

In human umbilical venous endothelial cells subjected to PDT with verteporfin there was a reduction in the cytosolic levels of Bax, although the total amount of the protein present in the cells did not change [72], and similar results were reported for murine leukemia L1210 cells sensitized with 9-capronyloxy-tetrakis (methoxyethyl) porphycene
(CPO) [59]. These results are in agreement with the described translocation of Bax to the mitochondria during apoptosis, where it oligomerizes and contributes to the efflux of apoptogenic proteins [45-47]. Overexpression of Bcl-2 in MCF 7c3 (human breast cancer cell line stably transfected with human procaspase-3 cDNA) inhibited PDT induced activation-associated conformational change of $\mathrm{Bax}$, and higher doses of the sensitizer Pc 4 were required to activate Bax in cells overexpressing Bcl-2 [98]. This may explain the protection conferred by the increased expression of Bcl-2 in MCF 7c3 cells [98]. However, no changes were observed in the amount of cytosolic Bax in human adenocarcinoma HeLa cells subjected to PDT with verteporfin [73], suggesting that, in this case, the protein may not play a role in the demise process.

The role of Bax in cytochrome $C$ release from mitochondria was investigated using Bax antisense oligonucleotides and by comparing the photodynamic effects of the Pc 4 photosensitizer in MCF 7c3 cells (human breast cancer cell line stably transfected with human procaspase-3 cDNA) and in DU-145 cells, a human prostate cancer cell line that lacks detectable amounts of Bax [99]. PDT-treated MCF-7c3 cells showed cytochrome $C$ release from mitochondria and apoptotic nuclei, whereas the latter cell type was not affected $[99,100]$. Also, treatment of MCF-7c3 cells with Bax antisense oligonucleotides reduced Pc 4PDT induced apoptotic death and restoration of Bax expression in DU-145 cells restored apoptosis, indicating that the lack of Bax is responsible for the resistance of these cells to PDT-induced apoptosis [100]. However, the fact that Bax-negative DU-145 cells are as sensitive to Pc 4-PDT as MCF-7c3 cells, as determined by the clonogenic assay, indicates that the commitment to cell death occurs at a step prior to Bax activation. In order to further investigate the role of Bax in cell death by PDT, MCF-7c3 and DU-145 cells were transfected with second mitochondriaderived activator of caspase (Smac)/direct inhibitor of apoptosis-binding protein with low pI (DIABLO) or Smac/DIABLO tagged with green fluorescent protein (GFP) at its C-terminus (Smac/DIABLO-GFP [99]). Smac/DIABLO is a protein of the mitochondrial intermembrane space, which is released together with cytochrome $C$ from mitochondria in response to apoptotic stimuli, and promotes caspase activation by inactivating the inhibition of apoptosis (IAP) [101,102]. PDT with Pc 4 induced the release of Smac/DIABLO-GFP in MCF-7c3 cells but not in DU-145 cells, and expression of the protein increased apoptotic death in the former cell type [99]. This suggests that Smac/DIABLO promotes cell death in Pc 4PDT in a Bax-dependent manner.

\section{Effect of PDT on the $\left[\mathrm{Ca}^{2+}\right]_{i}$ homeostasis}

Photodynamic treatment of various cell types has been shown to raise the $\left[\mathrm{Ca}^{2+}\right]_{i}[103-117]$, which may even- 
tually lead to cell death $[63,109,114,118]$. The calcium chelator BAPTA inhibited the release of cytochrome $C$, caspase-3 activation and apoptotic death of Chinese hamster V79 cells photosensitized with pheophorbide, indicating that $\mathrm{Ca}^{2+}$ indeed plays a role in PDT-induced apoptosis [63]. Chelation of intracellular $\mathrm{Ca}^{2+}$ with BAPTA also reduced apoptotic death of HeLa cells (human cervix carcinoma cell line) photosensitized with TBR, which is incorporated into the Golgi apparatus [87]. However, in some cell types it was observed that elevation of the $\left[\mathrm{Ca}^{2+}\right]_{\mathrm{i}}$ following photosensitization promotes cell survival and buffering of the intracellular $\mathrm{Ca}^{2+}$ enhanced cell death $[104,108,119]$. The $\left[\mathrm{Ca}^{2+}\right]_{\mathrm{i}}$ rise upon photosensitization may originate from the influx of $\mathrm{Ca}^{2+}$ through ion channels $[108,116]$, release of $\mathrm{Ca}^{2+}$ sequestered in internal stores, including the ER and possibly the mitochondria $[104,106,107,112,120]$, and/or activation of ion exchange mechanisms [111] (Fig. 2).

Some of the differences between the sources of $\mathrm{Ca}^{2+}$ contributing to the $\left[\mathrm{Ca}^{2+}\right]_{\mathrm{i}}$ rise may be due to the specificity of the sensitizers, and particularly of their targets within the cells. However, the $\left[\mathrm{Ca}^{2+}\right]_{\mathrm{i}}$ response in human fibroblasts sensitized with tetrasulfonated aluminum phthalocyanine $\left(\mathrm{AlPcS}_{4}\right)$ was mainly due to $\mathrm{Ca}^{2+}$ influx when low fluence rates were used, and to the release from internal stores at higher light doses [104]. The release of $\mathrm{Ca}^{2+}$ from internal stores, through the inositol 1,4,5-trisphosphate $\left(\operatorname{Ins}(1,4,5) \mathrm{P}_{3}\right)$ receptor, was shown to mediate the oscillatory pattern of the $\left[\mathrm{Ca}^{2+}\right]_{\mathrm{i}}$ response in isolated rat pancreatic acini sensitized with gadolinium porphyrinlike macrocycle B [106] or $\mathrm{AlPcS}_{4}$ [107]. Accordingly, the $\left[\mathrm{Ca}^{2+}\right]_{\mathrm{i}}$ oscillations induced by photosensitization of rat pancreatic acini were inhibited by U73122, an inhibitor of the phosphatidylinositol-4,5-bisphosphate-specific phospholipase C (PI-PLC), and this mechanism was also involved in the transient $\left[\mathrm{Ca}^{2+}\right]_{\mathrm{i}}$ increase observed in the mouse L5178Y lymphoma cells, sensitized with AlPc $[107,120]$. In contrast, D609, which inhibits the phosphatidylcholine-specific phospholipase $\mathrm{C}$, had no effect on the $\left[\mathrm{Ca}^{2+}\right]_{\mathrm{i}}$ response in sensitized rat pancreatic acini [107]. The $\left[\mathrm{Ca}^{2+}\right]_{\mathrm{i}}$ oscillations induced by photosensitization of pancreatic acinar cells with sulfonated aluminum phthalocyanine were inhibited by an antagonist of the cholecystokinin receptors [117], indicating that the photodynamic

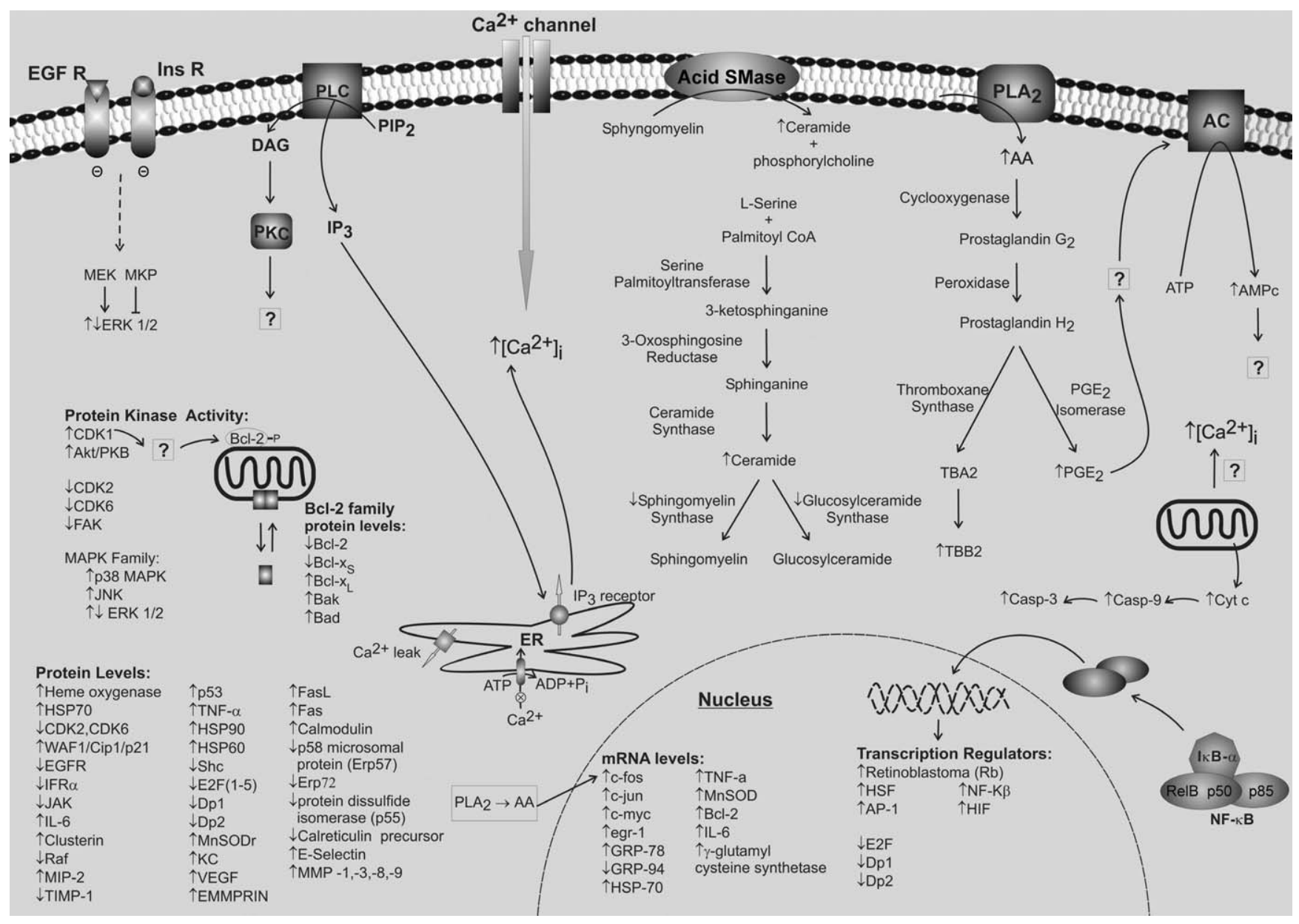

Fig. 2. Signalling mechanisms activated in PDT-treated cells. The diagram summarizes the results obtained in different tumor models using various sensitizers. $\uparrow$ and $\downarrow$ correspond to experimental observations where an increase or decrease of the abundance of the cellular component was observed. 
effects on the $\left[\mathrm{Ca}^{2+}\right]_{\mathrm{i}}$ may be secondary to the activation of plasma membrane-associated receptors.

In human adenocarcinoma HeLa cells photosensitized with verteporfin the release of $\mathrm{Ca}^{2+}$ from internal stores, mainly from the ER, was associated with a rapid caspaseindependent depletion of sarco/endoplasmic reticulum $\mathrm{Ca}^{2+}$ ATPase (SERCA2) [112]. Also, in vitro studies using subcellular fractions isolated from the rat liver showed that microsomal $\mathrm{Ca}^{2+}$-uptake mechanisms were more sensitive to photosensitization with haematoporphyrin or protoporphyrin than the influx of $\mathrm{Ca}^{2+}$ into isolated mitochondria [121]. The impairment of the $\mathrm{Ca}^{2+}$-uptake system in the ER may therefore contribute to the rise in the $\left[\mathrm{Ca}^{2+}\right]_{i}$, due to a change in the equilibrium rate of $\mathrm{Ca}^{2+}$ cycling across the store membrane, favoring the $\mathrm{Ca}^{2+}$ leak mechanism that contributes to the depletion of ER $\mathrm{Ca}^{2+}$ store [122]. Accordingly, selective SERCA inhibitors (thapsigargin, cyclopiazonic acid and 2,5-di-( $t$-butyl)-1,4-benzohydroquinone) increase the $\left[\mathrm{Ca}^{2+}\right]_{i}$ (e.g. see Refs. $\left.[123-125]\right)$ by permitting $\mathrm{Ca}^{2+}$ to leak out of the ER, and thapsigargin causes apoptotic cell death by a mechanism involving the activation of the ER associated caspase-12 in fibroblasts $[126,127]$. This caspase may be activated by caspase-7 and/or by calpains $[128,129]$, but whether calpains and caspase-12 play a role in PDT remains to be investigated. This pathway may be particularly significant in PDT-induced cell death using ER-localizing photosensitizers.

The plasma membrane $\mathrm{Ca}^{2+}$-ATPase has a high $\mathrm{Ca}^{2+}$ affinity, and it was recently shown to be inactivated in cells undergoing apoptosis due to cleavage by caspases [130]. Since the effector caspases are rapidly activated in PDT, the inactivation of the plasma membrane $\mathrm{Ca}^{2+}$-ATPases may also contribute to the rise in the $\left[\mathrm{Ca}^{2+}\right]$, particularly in the regions close to the plasma membrane.

\section{Activation of lipid metabolism by PDT}

\subsection{Phosphatidylinositol-specific phospholipase C (PI-PLC)}

The rise in the $\left[\mathrm{Ca}^{2+}\right]_{i}$ upon photosensitization may activate a number of intracellular events that shape cell demise, by interfering with subroutines of the death program. Photosensitization of the mouse lymphoma L5178Y cells with AlPc leads to a rapid accumulation of $\operatorname{Ins}(1,4,5) \mathrm{P}_{3}$ and increases the $\left[\mathrm{Ca}^{2+}\right]_{\mathrm{i}}$, mainly due to release from internal stores, and both events are significantly reduced by the phosphatidylinositol-specific phospholipase C inhibitor U73122 [120]. This phospholipase C inhibitor also inhibits $\left[\mathrm{Ca}^{2+}\right]_{i}$ spicking in rat pancreatic acini sensitized with $\mathrm{AlPcS}_{4}$ [107]. The mechanism of PI-PLC activation in PDT remains to be determined, but it may be secondary to a small rise in the $\left[\mathrm{Ca}^{2+}\right]_{\mathrm{i}}$ since the enzyme is activated by $\mathrm{Ca}^{2+}$ [131]. This phospholipase cleaves phosphatidylinositol 4,5-bisphosphate, to yield $\operatorname{Ins}(1,4,5) \mathrm{P}_{3}$ and diacylgly- cerol [132]. $\operatorname{Ins}(1,4,5) \mathrm{P}_{3}$ releases $\mathrm{Ca}^{2+}$ from internal stores contributing to the amplification of the $\left[\mathrm{Ca}^{2+}\right]_{\mathrm{i}}$ signal and, accordingly, the $\operatorname{Ins}(1,4,5) \mathrm{P}_{3}$ receptor inhibitor 2-aminoethoxydiphenylborate (2-APB) abolished the $\left[\mathrm{Ca}^{2+}\right]_{\mathrm{i}}$ spiking in rat pancreatic acini sensitized with $\mathrm{AlPcS}_{4}$ [107]. Diacylglycerol activates protein kinase $\mathrm{C}$, which may contribute or prevent cell death depending on the isoforms involved [133,134]. Inhibition of phospholipase C with U73122 was found to prevent the fragmentation of DNA resulting from the photosensitization of mouse lymphoma L5178Y cells with AlPc [120], suggesting that the release of $\mathrm{Ca}^{2+}$ from the internal stores and/or protein kinase $\mathrm{C}$ (PKC) activation plays an important role in PDT-induced apoptotic death. A role for PKC in PDT-induced cell was proposed based on the results showing that inhibition of PKC or down-regulation of the kinase activity by prolonged incubation with 12-O-tetradecanoylphorbol-13-acetate (TPA) prevented death of Chinese hamster ovary $(\mathrm{CHO})$ cells following photosensitization with aluminum phthalocyanine, as determined using the clonogenic assay [135].

\subsection{Phopholipase $A_{2}$ and arachidonic acid metabolites}

Photosensitization of different cell types was also shown to stimulate rapidly the release of arachidonic acid and of its metabolites [119,120,136-139]. The formation of arachidonic acid may result from the activation of phospholipase $\mathrm{A}_{2}$, an enzyme activated by $\mathrm{Ca}^{2+}$ (e.g. see Refs. [140, 141]) and, accordingly, inhibition of this enzyme with $p$-bromophenacyl bromide prevented DNA fragmentation induced by photosensitization of mouse L5178Y lymphoma cells with AlPc [120]. Although arachidonic acid may also arise from the sequential stimulation of phospholipase $\mathrm{C}$ (see above) and diacylglycerol lipase [142], the role of this pathway in PDT-induced cell death has never been investigated.

In T24 human bladder tumor cells photosensitized with the haematoporphyrin derivative (HPD), there was a $\mathrm{Ca}^{2+}$ dependent and indomethacin-sensitive transient release of prostaglandin $(\mathrm{PG}) \mathrm{E}_{2}$ and thromboxane $(\mathrm{TB}) \mathrm{B}_{2}$, the products of the metabolism of $\mathrm{PGH}_{2}$ generated by prostaglandin $\mathrm{E}$ isomerase and thromboxane $\mathrm{A}_{2}$ synthase (thromboxane $\mathrm{A}_{2}$ gives rise to thromboxane $\mathrm{B}_{2}$ ), respectively. In this case indomethacin enhanced photosensitivity, and pre-incubation of the cells with $\mathrm{PGE}_{2}$ prevented cell death, as determined using the clonogenic assay, indicating that the cyclooxygenase pathway activated during PDT protects cells from photodynamically inflicted damage in vitro [119]. However, the role of cyclooxygenases in PDT may actually depend on the cell genotype and/or the PDT dose, since pre-incubation of C6 glioma cells with indomethacin increased the number of cells surviving to PDT with HPD, whereas the survival rate for endothelial cells was decreased in the presence of the inhibitor when higher HPD concentrations were used [143].

Other studies have also shown that the arachidonic acid metabolism is changed in tumor cells subjected to PDT. 
Accordingly, $\mathrm{PGE}_{2}$ was transiently released by pancreatic acini photosensitized with AlPc sulfonate [138], and by photodynamic treatment of mouse RIF tumor cells and peritoneal macrophages (but not murine L929 fibroblasts) with Photofrin II [136]. Recent studies showed an enhanced cyclooxygenase-2 (COX-2) transcription in RIF cells subjected to PDT with Photofrin porfimer, and a long-term upregulation of the COX-2 protein levels was also observed [144]. In vitro studies with BA (mouse mammary carcinoma) and LLC (Lewis lung carcinoma) cells, using Photofrin porfimer as a sensitizer, also showed an up-regulation of COX-2 protein levels in photosensitized cells, and similar results were obtained in PDT-treated RIF tumors growing in $\mathrm{C} 3 \mathrm{H}$ mice [144]. The up-regulation of COX-2 was associated with an increase in the production of $\mathrm{PGE}_{2}$ in vivo and in vitro, and inhibition of the enzyme enhanced PDT responsiveness in RIF tumors [144]. In contrast, although PDT with hypericin also up-regulated COX-2 mRNA and protein levels, and stimulated the release of $\mathrm{PGE}_{2}$, in the T24 (human transitional cell carcinoma of the urinary bladder) and $\mathrm{HeLa}$ (human cervix carcinoma cells) cell lines, inhibition of the enzyme or exogenously added $\mathrm{PGE}_{2}$ was without effect on cell death [145]. Similarly, the fragmentation of DNA in mouse L5178Y lymphoma cells sensitized with AlPc was not affected by the COX inhibitor indomethacin, suggesting that the arachidonic acid metabolite important for inducing apoptosis may not be produced through the cyclooxygenasedependent pathway [120]. These results do not rule out a possible role for prostaglandins in in vitro PDT since these eicosanoids may also be produced by a noncyclooxygenase mechanism, catalyzed by free radicals produced as a result of photosensitization [146].

Administration of cyclooxygenase inhibitors to rats prior to PDT with Photofrin II prevented vessel constriction and changes in permeability, suggesting that metabolites produced by the cyclooxygenase-dependent pathway play a role in these events [147-149]. Thromboxane appears to play a major role in these effects and on tumor response, since inhibition of thromboxane synthase or of thromboxane receptors significantly reduced vessel constriction, inhibited vessel permeability and reduced tumor cure [150]. However, in vivo studies using four different zinc phthalocyanines showed that the release of eicosanoids and the role of the cyclooxygenases in PDT depend on the photosensitizer used [139].

\subsection{Ceramide}

Ceramide is a stress-induced second messenger that may be generated by sphingomyelinases, which cleave sphingomyelin to yield ceramide and phosphorylcholine, or by de novo synthesis by a synthase [151]. The initial step in the latter pathway is catalyzed by serine palmitoyltransferase, which gives rise to 3-ketosphinganine from L-serine and palmitoyl CoA. 3-Ketosphinganine is then reduced to sphinganine, and acylation follows to produce ceramide
[85]. Depending on the target cell, ceramide may induce diverse biological responses, including apoptosis, cell cycle arrest, differentiation and proliferation [151,152]. Ceramide is converted into sphingomyelin and glucosylceramide in reactions catalyzed by phosphatidylcholine:ceramide phosphocoline transferase (sphingomyelin synthase) and UDPglucose:ceramide glucosyl transferase (glucosylceramide synthase), respectively [153].

Ceramide accumulation was observed in response to photodynamic treatment of L5178Y mouse lymphoma cells, human leukemia (U937) cells, Jurkat human lymphoma cells, CHO cells, A431 human epidermoid carcinoma cells, normal human lymphoblasts and mouse embryo fibroblasts with Pc 4 [154-159]. The studies performed in $\mathrm{CHO}$ and Jurkat cells showed that PDT inactivates sphingomyelin synthase and glucosylceramide synthase, with no up-regulation in serine palmitoyltransferase activity, indicating that de novo accumulation of ceramide is due to inhibition of its conversion to complex sphingolipids rather than to an increase in the mechanisms of synthesis [159]. In fact, in $\mathrm{CHO}$ cells subjected to Pc 4-PDT, there was a reduction in LCB1 protein levels, one of the subunits of serine palmitoyltransferase [159]. Furthermore, the activity of acid sphingomyelinase was inhibited in human epidermoid carcinoma A431 cells upon photosensitization with the same sensitizer [158].

Sensitization of the colon cell line HCT-116 with pyropheophorbide-a methyl ester (PPME) leads to the accumulation of ceramide, through the activity of the acid sphingomyelinase [160]. Accordingly, Niemann-Pick disease lymphoblasts, which lack acid sphingomyelinase activity, failed to respond to PDT with ceramide accumulation and apoptotic death [156]. These results suggest that ceramide generation by sphingomyelinase may be the cause of apoptotic death in PDT. Although the role of the plasma membrane-associated neutral sphingomyelinase in the demise process has not been investigated in detail, studies in the colon cancer HCT-116 cell line sensitized with PPME showed no activation of the enzyme [160].

Photosensitization of Jurkat cells with Pc 4 induced intracellular accumulation of sphinganine and ceramide, and apoptotic death was reduced by the serine palmitoyltransferase inhibitor ISP-1 (Myriocin), an inhibitor of de novo sphingolipid synthesis $[85,159]$. In addition, PDTinduced sphinganine accumulation and apoptotic death were also inhibited by ISP-1 in A431 human epidermoid and HT29 human carcinoma cells [85]. ISP-1 also inhibited PDT-induced caspase-3-like activity and PARP cleavage in PDT-treated Jurkat cells, but it was without effect on the collapse of the mitochondrial membrane potential and on cytochrome $C$ release from the mitochondria [85,161], suggesting that de novo accumulated sphinganine and/or ceramide initiates apoptosis downstream of cytochrome $C$ release from mitochondria. Similar results were obtained in a study using $\mathrm{CHO}$ cells photosensitized with Pc 4 [159]. However, the role of de novo ceramide synthesis in the 
demise process in photosensitized cells may depend on the cell type since fumonisin B1, an inhibitor of ceramide synthase, had no effect on apoptosis in embryonic fibroblasts sensitized with Pc 4 [49]. A number of targets of ceramide have been identified [151,152], including the stress-activated protein kinase cascade $[162,163]$, which is activated in PDT (see below).

\section{Role of cyclic nucleotides in PDT}

\section{1. $c A M P$}

In vitro photosensitization of human bladder transitional carcinoma cells (clone T24) with HPD stimulated rapidly and transiently the intracellular accumulation of cAMP. This effect was suppressed by indomethacin, a cyclooxygenase inhibitor, which enhanced the photodynamically induced loss of clonogenicity [164]. These results indicate that the cytoprotective effect of $\mathrm{PGE}_{2}$ in these cells is mediated by an increase in the intracellular cAMP content. In Chinese hamster V79 cells photosensitized with pheophorbide a, the protective effect of cAMP against apoptotic death was found to occur at a level downstream of cytochrome $C$ release from the mitochondria, and upstream of caspase-3 activation [63].

\subsection{Nitric oxide and cGMP}

Nitric oxide (NO) plays an important role in tumor cell biology since it increases blood flow in the tumor, thereby promoting tumor growth [165] and facilitating metastasis [166]. Activation of macrophages by photosensitization with mTHPC stimulated the release of nitric oxide [167], and nasopharyngeal carcinoma CNE2 cells sensitized with hypericin showed an increase in the activity of nicotinamide adenine dinucleotide hydrogen phosphate-diaphorase (NADPH-d, a potential marker of NO synthase activity) and in the immunoreactivity of the nitric oxide synthase (NOS) I and II [168]. Using an electrochemical sensor for online measurement of NO changes, Dalbasti et al. [169] detected a transient rise in NO production in the cerebellum as a result of ALA-mediated PDT. This was probably due to the rapid activation of the neuronal isoform of NOS, which is constitutively expressed and is activated by $\mathrm{Ca}^{2+}$ and calmodulin [170]. Taken together, these evidences indicate that PDT may affect NO production in the photosensitized tissues.

NO is expected to play a complex role in PDT, since several of the tissue changes following photosensitization, including (i) vascular responses, (ii) the massive neutrophil recruitment and (iii) cell death (Refs. [149,171-174]; see also references above), have been shown to be modulated by NO in other systems [175-177]. Subcutaneous tumors generating low levels of $\mathrm{NO}$ were found to be more sensitive to PDT with Photofrin ${ }^{\circledR}$ than those containing high levels of NO, and the administration of the NOS inhibitor $N^{\mathrm{G}}$-nitro-L-arginine, together with PDT treatment, enhanced tumor regression $[178,179]$. Since in these studies the NOS inhibitor reduced the blood flow in the tumor, this may explain the increase in PDT efficiency [179]. In addition, the possibility that NO generated by tumor cells and by endothelial cells of the tumor microvasculature may directly affect tumor cell death cannot be excluded, since NO has been shown to protect cells from different apoptotic stimuli [180]. This hypothesis was recently evaluated using in vitro photosensitization systems [181-183]. Pre-incubation of human lymphoblastoid CCRF-CEM cells with NO donors or L-arginine, the NOS substrate, decreased cell death by apoptosis induced by photosensitization with bisulfonated aluminum phthalocyanine $\left(\mathrm{AlPcS}_{2}\right)$, by a mechanism independent of $S$-nitrosylation of caspase-3-like enzymes. The protective mechanism induced by $\mathrm{NO}$ was mediated by the activation of protein kinase $\mathrm{G}$, and occurred at a level upstream of caspase-9 processing [183]. Although the protective effect of $\mathrm{NO}$ against apoptotic death in several models has been attributed to an increase in the expression of heme oxygenase-1, heat shock protein 70 or Bcl-2 [184186], this was not the case in the protection of CCRF-CEM cells from photosensitization by pre-exposure to NO [183]. The presence of NO during the photosensitization period intercepted lipid-derived radicals and protected COH-BR1 cells (human breast tumor line) from necrotic cell death, in experiments where sensitization was induced via de metabolism of added ALA to PpIX $[182,187]$.

\section{Role of MAPKs and CDKs in PDT}

The mitogen activated protein kinases (MAPKs) are a group of serine/threonine protein kinases, activated by dual phosphorylation on a tyrosine and a threonine residue. The three members of this family of kinases include the extracellular signal regulated kinases (ERKs), the c-Jun $\mathrm{N}$ terminal kinases/stress activated protein kinases (JNK/ SAPKs), and the p38 MAPK. Each of these enzymes participates in closely related signaling cascades that ultimately contribute to the regulation of gene expression in response to a variety of stimuli. Although activation of ERK $1 / 2$ is generally associated with cell survival, and p38 MAPK and JNK linked to induction of apoptosis, the role of each MAPK in cell death is dependent on the cell type and on the physiological context $[188,189]$.

Activation of JNK and p38 MAPK, but not of ERK1 and ERK2, was observed for murine Pas 212 keratinocytes in response to oxidative stress produced by photoactivation of benzoporphyrin derivative, at near cytotoxic levels [190]. Similar findings were reported for human $\mathrm{HaCaT}$ keratinocytes and for the hypopharyngeal carcinoma FaDu subjected to ALA-PDT [191,192], and in human adenocarcinoma HeLa cells treated with low hypericin-PDT doses [81]. When this mode of sensitization was used, an increase in the phosphor- 
ylation (activity) of p38 MAPK was also observed in the human melanoma cell lines Bro and SkMel-23 [191]. Photoactivation of $\mathrm{Pc} 4$ also increased the activity of JNK in murine LY-R leukemic lymphoblasts and CHO cells, whereas the activity of p38 MAPK was stimulated only in CHO cells. Also, under the same conditions a reduction in the phosphorylation of ERK2 was observed in CHO cells, but not in LY-R leukemic lymphoblasts [193]. Taken together the results suggest that the role of MAPKs in PDT may depend on the cell type, the photosensitizer used and/or the light dose used.

The photosensitizer that is best characterized in terms of its effects on MAPK activity and the role of these kinases in cell death is hypericin. Photoactivated hypericin stimulated JNK activity and produced an irreversible inhibition of the activity of ERK2 in A431 (human epidermoid carcinoma cells), human HaCaT keratinocytes, murine L929 fibroblasts and human adenocarcinoma HeLa cells [80]. In agreement with the results with the other sensitizers, PDT with hypericin also produced a sustained activation of p38 MAPK in HeLa cells [80]. The effect of photosensitization with hypericin on the activity of stress-activated kinases in this cell line was not affected by pretreatment with the antioxidants $N$-acetylcysteine or butylated hydroxyanisole [80], in contrast with the role of reactive oxygen species in the activation of JNK1 and p38 MAPK in photosensitized murine keratinocytes [190]. T24 cells (human transitional cell carcinoma of the urinary bladder) bear an oncogenic $\mathrm{H}-$ ras mutation, and the p38 MAPK and the Raf-ERK cascades are constitutively active. When this cell line was subjected to hypericin-PDT ERK activity was also partly inhibited, as observed for the other cell lines (see above), but the phosphorylation level of p38 MAPK dropped drastically to undetectable levels, followed by a de novo activation of the kinase [145]. In these cells, p38 MAPK activity may account for the observed stabilization of COX2 mRNA levels and for the up-regulation of its protein levels following photosensitization with hypericin [145].

Although caspase inhibitors prevented death of HeLa cells sensitized with hypericin, they were without effect on the JNK1 and p38 MAPK activation [80], indicating that caspase activation is either unrelated or lies downstream from these MAPKs. Furthermore, inhibition of the JNK and p38 MAPK pathways enhanced PDT induced apoptotic death, suggesting that these MAPKs play an important role in counteracting the effects of photosensitization with hypericin.

Although mitochondria-associated Bcl-2 was phosphorylated in human adenocarcinoma HeLa cells subjected to sub-lethal PDT doses, in relation to $\mathrm{G}_{2} / \mathrm{M}$ cell cycle arrest, preceding apoptosis, this effect could not be attributed to MAPKs [81]. By contrast, a pathway involving CDK1 was found to be responsible for the phosphorylation of mitochondria-associated Bcl-2, on Ser70, and this may constitute a signal to delay apoptosis in $\mathrm{G}_{2} / \mathrm{M}$-phase arrested HeLa cells [81]. Increasing the photodynamic stress using higher doses of hypericin promptly caused apoptosis in HeLa cells, during which Bcl-2 was not phosphorylated, probably because the photodamage was pushed over a threshold level which results in a rapid activation of the cell death machinery [81]. In contrast to the role of the p38 MAPK in PDT based on the studies using hypericin (see above), inhibition of the kinase with SB202190 protected murine LY-R leukemic lymphoblasts and $\mathrm{CHO}$ cells from apoptotic death induced by photosensitization with Pc 4 [193]. Similar results were obtained in the murine fibroblast cell line NIH 3T3 and in the human leukemia HL60 cells, using Rose Bengal as a sensitizer $[44,194]$. The effect of p38 MAPK in LY-R leukemic lymphoblasts occurred at a level upstream of caspase- 9 and caspase- 3 activation, and inhibition of p38 MAPK also prevented caspase- 3 activation in HL60 cells subjected to PDT with Rose Bengal.

Taken together the available evidence suggests that the effect of PDT on the activity of MAPKs depend on the cell line and/or photosensitizer used. Tong et al. [195,196] addressed this question by comparing the effect of Photofrin ${ }^{\circledR}$-mediated PDT on the activation of MAPKs in immortalized Li-Fraumeni syndrome (LFS087) cells and in a normal human fibroblast cell line (GM38A), using equivalent cellular levels of the sensitizer. The former cell line is considerably more resistant to Photofrin ${ }^{\circledR}$-mediated PDT when compared with normal human fibroblasts and showed a sustained activation of JNK1 and phosphorylation (activation) of p38 MAPK and of ERK1/2 [196]. In contrast, photosensitization of the normal human fibroblast cell line GM38A induced a transient activation of the three MAPKs, and the reduction in ERK1/2 phosphorylation after the initial peak was correlated with an up-regulation in the expression of mitogen-activated protein kinase phosphatase 1 (MKP-1), which dephosphorylates ERK1/2 [195]. The sustained activation of ERK1/2 in the LFS087 cell line might result from the low levels of expression of MKP-1, which may not reach the threshold required for dephosphorylation of the kinase. Although Raf-1 is normally involved in the regulation of ERK1/2, this is probably not the case in photosensitized LFS087 and in GM38A cells, since Photofrin ${ }^{\circledR}$-mediated PDT significantly reduced Raf-1 protein levels [195]. Inhibition of ERK1/2 phosphorylation with PD098,059 increased the sensitivity of LFS087 cells to Photofrin ${ }^{\circledR}$-mediated PDT, suggesting that this pathway protects the cells from cell death [195]. In contrast, blocking the p38 MAPK in LFS087 cells, by transient infection with a recombinant adenovirus expressing a dominant negative mutant of p38 MAPK, or in human adenocarcinoma HeLa cells, by stable transfection with a dominant negative mutant of p38 MAPK, had no effect on cell survival following Photofrin ${ }^{\circledR}$-mediated PDT [196].

\section{Differential effect of PDT on tyrosine kinases}

Protein tyrosine phosphorylation increased rapidly in the mouse lymphoma L5178Y-R cells upon photosensitization with Pc 4 [197], and the immunoreactivity with an antibody 
that specifically recognizes phosphotyrosine also increased in extracts prepared from murine mastocytoma P815 cells subjected to PDT with benzoporphyrin derivative monoacid ring A [198]. Although the intracellular events responsible for the up-regulation of protein tyrosine phosphorylation in photosensitized cells have not been determined, they may be, at least in part, secondary to a rise in the $\left[\mathrm{Ca}^{2+}\right]_{\mathrm{i}}$ (e.g. see Ref. [199]). Tyrosine phosphorylation of proteins in L5178Y-R cells photosensitized with Pc 4 was amplified by pre-incubating the cells with the tyrosine phosphatase inhibitor sodium orthovanadate [197], indicating that the effect of PDT on tyrosine phosphorylation is rapidly counteracted by tyrosine phosphatases. Although the lack of effect of sodium orthovanadate on PDT with Pc 4 [197] suggests that the demise pathways do not rely on a broad increase in tyrosine phosphorylation, further studies will be required in order to establish the general role of tyrosine kinases in cell death upon photosensitization.

Stimulation of tyrosine kinase activity and phosphorylation of the $80-\mathrm{kDa}$ c-Src substrate HS1 (haematopoietic lineage cell-specific protein 1) occurred rapidly in murine L5178Y-R leukemic lymphoblasts following photoactivation of Pc 4 [197], under conditions where cell death occurred by apoptosis. HS1 is a protein found in the cytoplasm and to a lesser extent in the nucleus of essentially all haematopoietic cells [200], and it was found to play a role in antigen-receptor-induced apoptosis in the murine Blymphoma WEHI-231 cells [201]. This protein also plays an important role in the signaling from surface IgM leading to apoptosis in peritoneal B cells [202], but the role of HS1 in PDT is still not known.

Photosensitization of membrane fractions isolated from human epidermoid carcinoma A431 cells and 3T3 HIR mouse fibroblast cells with hypericin inhibited irreversibly the protein tyrosine kinase activity of the epidermal growth factor (EGF) and insulin receptors, but it was without effect on the activity of the cytosolic protein tyrosine kinases Lyn, Fgr, TPK-IIB and c-Src kinase [203]. Treatment of FaDu cells (hypopharyngeal carcinoma) with ALA-PDT caused an extensive reduction in the amount of EGF receptor (EGFR) protein levels, and of the phosphorylation of ERK following stimulation of the receptors [192]. Studies using the human epidermoid carcinoma A431 cells, which express high levels of the EGFR, also showed that PDT with Pc 4 result in a rapid time-dependent reduction in the EGFR protein levels and in receptor phosphorylation on tyrosine, under conditions where cell death occurred by apoptosis. A similar reduction in the levels of Shc (52- and 46-kDa isoforms), a protein that belongs to the signaling machinery of the receptor, was also observed, in addition to a decrease in its phosphorylation on tyrosine, further indicating that PDT decreases the signaling activity of these receptors [82]. Similar results were obtained in in vivo experiments, where chemically as well as ultraviolet $\mathrm{B}$ radiation-induced squamous papillomas, in SENCAR and SKH-1 hairless mice, respectively, were subjected to Pc 4-PDT [82]. The EGFR is considered to enhance cell proliferation, motility, adhesion, invasion and angiogenesis [204] and, therefore, the rapid effect of photosensitization on the EGFR protein levels, and on its signaling machinery, may be a cause rather than a consequence of cell death in PDT.

$\mathrm{Akt} / \mathrm{PKB}$ is a serine/threonine kinase that plays an important role in cell survival, being activated downstream of the phosphatidylinositol-3-kinase (PI3-K) upon stimulation of numerous receptors for growth factors [205-208]. Photosensitization of the murine fibroblast cell line NIH $3 \mathrm{~T} 3$ with Rose Bengal increased the phosphorylation of Akt on serine 473 , which is taken as a sign of kinase activation [194]. This effect was mediated by activation of PI3-K, but was independent of activation of growth factor receptors and of FAK, a tyrosine kinase. Indeed, photosensitization with Rose Bengal decreased FAK phosphorylation (activity), which may explain the reduction in cell adhesion [194]. However, it remains to be determined whether Akt/PKB activation modulates the demise process in photosensitized cells.

The non-receptor tyrosine kinase Etk/Bmx (epithelial and endothelial tyrosine kinase or bone marrow tyrosine kinase gene in chromosome $\mathrm{X}$ ), which showed activity in resting LNCaP prostate cancer cells, downstream of PI3-K, provided some protection to these cells from apoptotic death induced by PDT with Pc 4 [84]. However, the mechanism of action of Etk/Bmx in photosensitized cells is not known.

The response of hypopharyngeal carcinoma FaDu cells and of cultured human pulmonary fibroblasts to IL-6-type cytokines (IL-6, LIF [leukemia inhibitory factor] and oncostatin M), namely STAT (signal transducers and activators of transcription) phosphorylation on tyrosine, was also significantly impaired after photosensitization with ALA or Photofrin ${ }^{\circledR}$. Under the same conditions it was observed a reduction of the fully processed plasma membrane form of the leukemia inhibitory factor receptor- $\alpha$ (LIFR $\alpha$ ), but no significant effect was observed on the proteins oncostatin receptor- $\beta$ (OSMR $\beta$ ) and gp130 [192]. The reduction in LIFR $\alpha$ could account for the loss of responsiveness to LIF, whereas the lack of activity of OSM in photosensitized cells may be due to an impairment of the functionality of those receptor subunits and/or of the signaling pathway downstream of the receptors [192]. Accordingly, JAK1 (Janus kinase 1) protein levels were decreased in cervical adenocarcinoma HeLa cells subjected to PDT with ALA [192]. Signaling by IL-6-type cytokines has been associated with the control of function of differentiated cells [209-211] and with suppression of proliferation of various epithelial cells [212, 213].

\section{Regulation of transcription factors in PDT}

\subsection{Transcription factor activator protein-1 (AP-1)}

AP-1 is a homo- or heterodimeric protein complex, composed of Jun (c-Jun, Jun-B, Jun-D), Fos (c-Fos, Fos-B, Fra-1, Fra-2), Maf (c-Maf, MafB, MafA, MafG/F/K and Nrl) 
and ATF (ATF2, LRF1/ATF3, B-ATF, JDP1, JDP2) -family proteins. This family of transcription factors is activated by a variety of physical and chemical stresses and recognize either cAMP response elements (CRE, TGACGTCA) or TPA response elements (TGAG/CTCA). AP-1 transcription factors have been related to both induction and prevention of apoptosis, depending on the tissue and on its developmental stage (reviewed in [214,215]).

Photosensitization of murine RIF-1 cells with Photofrin, Npe6 (mono-L-aspartyl chlorin $\mathrm{e}_{6}$ ) or with Rose Bengal increased c-fos mRNA levels. PDT with Photofrin ${ }^{\circledR}$ also increased transiently c-jun, c-myc and egr-1 mRNA in the same cells [216], and c-fos and c-jun mRNA in human adenocarcinoma HeLa cells [217]. Furthermore, mRNA stability experiments showed an increased half-life of cfos and c-jun transcripts in HeLa cells sensitized with Photofrin ${ }^{\circledR}$, and a concomitant increase in AP-1-DNA binding activity was also observed [217,218]. An increase in AP-1 DNA binding activity was also observed in Photofrin-PDT using mouse leukemia L1210 cells [219] and the human keratinocyte PAM 212 cell line. Inhibition of protein kinases, with staurosporin, or of phospholipase $A_{2}$, with quinacrine, blocked the induction of c-fos mRNA in RIF-1 cells sensitized with Photofrin ${ }^{\circledR}$ [216], suggesting that these pathways may participate in the signaling mechanisms leading to activation of early response genes. This is in agreement with the results showing that AP-1 is activated by p38 MAPK and JNK [214], two protein kinases that are stimulated in photosensitized cells (see Section 5). However, the signaling cascade responsible for AP-1 activation in PDT remains to be determined.

\subsection{Transcription nuclear factor kappa $B(N F-\kappa B)$}

Under resting conditions the transcription factor NF-kB is present in the cytoplasm as homo- or heterodimers, formed by association of subunits belonging to a protein family that includes p50, p52, p65 (RelA), RelB and cRel. These complexes are sequestered in the cytoplasm by proteins belonging to the inhibitor of NF-kB (IкB) family, including $\mathrm{I} \kappa \mathrm{B} \alpha$, I $\kappa \mathrm{B} \beta, \mathrm{I} \kappa \mathrm{B} \varepsilon, \mathrm{p} 100$ and $\mathrm{p} 105$. Stimuli leading to NF- $\kappa \mathrm{B}$ activation typically initiate a specific signal transduction cascade leading to phosphorylation of I $\mathrm{B}$ Bs. Once phosphorylated, I $\mathrm{KB}$ is selectively ubiquitinated and degraded by the $26 \mathrm{~S}$ proteosome, releasing NF$\kappa \mathrm{B}$ that is then translocated to the nucleus where it participates in transcriptional activation (reviewed in Refs. $[220,221])$. NF-kB has been shown to either promote or inhibit apoptosis, depending on the cell type and the type of inducer [222-224].

PDT has been shown to induce NF- $\mathrm{B}$ activity in various cell models and using different sensitizers, but limited information is available concerning the role of the transcription factor in the demise process. Activation of $\mathrm{NF}-\kappa \mathrm{B}$ upon photosensitization was first shown in studies using mouse leukemia L1210 cells and Photofrin II as a sensitizer [219]. Photosensitization of the lymphocytic ACH-2 cells with proflavine (PF) or with methylene blue led to the degradation of $I \kappa B \alpha$ and increased NF- $\kappa B$ (p50 and p65) DNA-binding activity $[225,226]$. Similar results were obtained in the promyelocytic leukemia HL-60 cells sensitized with the benzoporphyrin derivative monoacid ring $\mathrm{A}$ (verteporfin), in which $\mathrm{I} \kappa \mathrm{B} \beta$ levels were maintained unchanged [79]. Furthermore, HeLa cells (human cervix carcinoma cells) and T24 cells (human transitional cell carcinoma of the urinary bladder) photosensitized with hypericin also showed a reduction in the cytosolic levels of $\mathrm{I} \kappa \mathrm{B} \alpha$, which correlated in time with binding of nuclear proteins to the NF-kB site of the cox-2 promoter [145]. The activation of NF-KB and its role in cell death upon photosensitization was investigated using the sensitizer PPME [160,227] and its derivative aminopyropheophorbide (APP) [228], which results from the addition of a positively charged group that increases cellular uptake. PPME-mediated photosensitization of HCT-116 human colon carcinoma cells activated NF- $\mathrm{BB}$ by triggering the signaling pathway mediated by the IL-1 receptor. This involved degradation of the cytoplasmic I $\kappa \mathrm{B} \alpha$ pool, but not of I $\mathrm{KB} \beta, \mathrm{p} 105$ or $\mathrm{p} 100$, and supershift assays using antibodies against the NF- $\kappa B$ proteins showed that p50 and RelA contributed to the increase in NF-kB DNA binding activity in photosensitized cells [160]. Concomitant with NF- $\mathrm{BB}$ activation in human ECV 304 and HMEC-1 endothelial cells photosensitized by PPME, I $\mathrm{K} \alpha \alpha$ was also degraded, and a slight modification in the I $\mathrm{B} \beta \beta$, I $\mathrm{k} \varepsilon$, p100 and p105 levels was observed [227]. Interestingly, in this case the activation of NF- $\kappa \mathrm{B}$ was proposed to occur by a mechanism independent of the activation of ІкB kinases and require the activity of a tyrosine kinase [227]. Expression of a dominant negative mutant of I $\mathrm{B} \alpha$ increased apoptotic death of HCT-116 cells sensitized with APP [228], suggesting that NF- $\mathrm{B}$ regulates the expression of gene(s) encoding proteins with an anti-apoptotic activity. However, it was not determined whether cells prevented from undergoing apoptosis in the presence of the dominant negative mutant of $\mathrm{I} \kappa \mathrm{B} \alpha$ died by a non-apoptotic mechanism.

\subsection{Retinoblastoma $(R b)$ and E2F family of transcription factors}

Photosensitization of A431 human epidermoid carcinoma cells with Pc 4 resulted in inhibition of cell growth and $\mathrm{G}_{0}-\mathrm{G}_{1}$ phase arrest of the cell cycle. This effect was associated with a time-dependent inhibition of the expression and activity of CDK2 and CDK6, two critical kinases operative in the $G_{1}$ phase of the cell cycle, and of their regulatory partners cyclin E and cyclin D1 [229]. In the same study it was found that PDT up-regulates the expression of the cyclin kinase inhibitor WAF1/CIP1/ p21, thereby increasing its binding towards cyclin D1 and CDK6. A decrease in the binding of cyclin D1 toward 
CDK2 and CDK6 was also observed [229]. An upregulation in the $\mathrm{WAF} 1 / \mathrm{CIP} 1 / \mathrm{p} 21$ protein levels was also observed upon photosensitization of human ovarian carcinoma (OVCAR-3)-bearing athymic nude mice with Pc 4 [230], but not in SW480 colon cancer xenographs subjected to PDT with the same sensitizer [231]. These observations suggest that induction of cell death in these tumors may be triggered by a WAF1/CIP1/p21-independent mechanism.

The cyclin D/CDK4/6, cyclin A/CDK2 and cyclin E/ CDK2 complexes are involved in the phosphorylation of $\mathrm{Rb}$ during the cell cycle (reviewed in Ref. [232]), and the observed changes in CDKs in photosensitized cells may account for the observed reduction in $\mathrm{Rb}$ phosphorylation [233]. A reduction in Rb phosphorylation in PDT may be responsible for the induction of WAF1/CIP1/p21 (when observed), since the predominance of hypo-phosphorylated $\mathrm{Rb}$ was previously associated with the induction of the protein [234]. Hypo-phosphorylated Rb is also capable of associating and thereby inhibiting the activity of the E2F family of transcription factors (E2F [235,236]), which are involved in the regulation of cell cycle [232]. More recently evidences were provided for an active role of $\mathrm{Rb}$ in gene repression through the $\mathrm{Rb}-\mathrm{E} 2 \mathrm{~F}$ complex binding to a promoter, thereby contributing to growth arrest [237]. The photodynamic response in human epidermoid carcinoma A431 cells sensitized with Pc 4 was accompanied by a down-regulation of five members of the E2F (1-5) transcription factor family, and of their heterodimeric partners $\mathrm{DP} 1$ and DP2 [233]. Since Rb and E2F regulate the G1 $\rightarrow \mathrm{S}$ transition in the cell cycle (reviewed in Refs. [232,237]), the reduction in $\mathrm{Rb}$ phosphorylation and in the E2F and DP1 and 2 protein levels may be responsible for imposing an artificial checkpoint at this phase, leading to a $\mathrm{G}_{0} / \mathrm{G}_{1}$ arrest and a subsequent apoptotic death.

\section{Changes in protein levels in response to PDT}

\subsection{Heme oxygenase}

The oxidative stress caused by PDT has been shown to induce the expression of several proteins typically associated with cellular responses to stress conditions. Photosensitization of Chinese hamster fibroblast cells (V-79) with Photofrin II or with Rose Bengal increased heme oxygenase protein levels [238]. Heme oxygenase catalyzes the oxidative degradation of heme to biliverdin, which is then converted into bilirubin by biliverdin reductase [239,240]. Bilirubin and biliverdin are efficient anti-oxidants [241] (reviewed in Ref. [242]). The heme oxygenase gene contains binding sites for several transcription factors, including an AP-1 consensus sequence [243] (reviewed in Ref. [242]) that may contribute to an up-regulation of gene expression since this transcription factor may be activated in PDT (see above).

\subsection{Glucose-regulated proteins}

PDT with Photofrin II increased the mRNA encoding glucose-regulated proteins (GRP-78 and GRP-94) in mouse RIF-1 cells [244]. In vivo studies also revealed a transient elevation of GRP-78 mRNA in transplanted mouse mammary carcinomas photosensitized with Photofrin II [244]. Investigation of the mechanism of cell death in human ovarian carcinoma A2780 cells treated with structurally diverse $N$-(2-hydroxypropyl)-methacrylamide (HPMA) copolymer $(\mathrm{P})$-mesochlorin $\mathrm{e}_{6}$ monoethylenediamine $\left(\mathrm{Mce}_{6}\right)$ conjugates that possess differential subcellular accumulation or covalent attachments of photosensitizers (or both) showed that a conjugate that targets the nucleus selectively abolished GRP-94 expression [15]. In this study, A2780 cells photosensitized with a conjugate possessing $\mathrm{Mce}_{6}$ linkage via a lysosomally degradable tetrapeptide spacer (HPMA copolymer-Mce ${ }_{6}$ conjugate containing $\mathrm{Mce}_{6}$ bound via the glycylphenylalanylleucylglycine (GFLG) linker) selectively increased mRNA levels for HSP-70 in a transient manner [15].

\subsection{Heat-shock proteins}

In vivo and in vitro studies using a chlorin (Npe6)- or purpurin (tin etio-purpurin)-based sensitizer also showed an increased in HSP-70 mRNA and protein levels in murine RIF-1 cells subjected to PDT [245]. Interestingly, a similar increase in HSP-70 was observed in in vivo but not in vitro studies using Photofrin II [245]. Metabolic studies aiming at determining changes in protein synthesis caused by in vitro and in vivo PDT with benzoporphyrin derivative revealed that the pattern of expression was similar in both cases. Using two-dimensional gel electrophoresis and by comparison with published gel patterns, the proteins whose expression changed upon PDT were identified as HSP-110, HSP90, HSP-73, HSP-72, HSP-47, GRP-100 and GRP-80 [246]. The transcription of genes belonging to the heat shock family is regulated by a mechanism involving the binding of heat-shock factors (HSF) to specific heat-shock elements (HSE). In nonstress conditions the transcription factor HSF is found in the cytoplasm, in a monomeric form, associated with HSP-70 [247]. During cellular stress HSP-70 binds to denatured proteins, freeing HSF that trimerizes and migrates to the nucleus, where it binds to HSE [247]. Accordingly, in vitro photosensitization of the RIF tumor cells with Npe6 induced HSF-1 binding to HSE, and transiently induced the expression of a reporter gene containing an inducible hsp 70 promoter [248]. This was not observed when Photofrin was used as a sensitizer, possibly due to differences in the subcellular targets of the molecules [245]. Interestingly, HSF binding to HSE and reporter gene expression was observed for Npe6- and Photofrin ${ }^{\circledR}$-mediated in vivo PDT studies, when RIF cells were grown as solid tumors in mice [248]. Also, in vivo and in vitro studies, using a mouse mammary EMT6 cell line stably transfected with a plasmid 
consisting of the gene for GFP under the control of an hsp70 promoter, showed that sublethal doses of meso-tetra(hydroxy)phenyl chlorin (mTHPC; Foscan ${ }^{\circledR}$ )-PDT induce hsp70driven GFP expression [249]. The up-regulation in HSP-70 [250] and HSP-90 protein levels may protect the cells from apoptotic death induced by PDT since both proteins interact with the apoptotic machinery thereby suppressing apoptosis. Indeed, HSP-70 binds to the caspase-recruitment domain (CARD) of Apaf-1 and prevents the recruitment of procaspase-9 to the apoptosome complex [251,252]. HSP-90 is also a negative regulator of the mitochondrial apoptotic pathway, which acts by forming a cytosolic complex with Apaf-1, which inhibits the formation of the active apoptosome complex [253].

\subsection{Anti-oxidant enzymes and apoptosis regulatory proteins}

Recent studies using murine colon-26 (C26) cells, a poorly differentiated colon adenocarcinoma cell line, showed that PDT with Photofrin increases the protein levels of manganese superoxide dismutase (MnSOD), but not of $\mathrm{Cu}, \mathrm{Zn}-\mathrm{SOD}$ [254]. Previous studies using human adenocarcinoma HeLa cells also showed induction of MnSOD mRNA following photosensitization with Photofrin II [255]. Transient transfection of the T24 bladder cancer cell line with the MnSOD gene, but not with the $\mathrm{Cu}, \mathrm{Zn}-\mathrm{SOD}$ gene, or pretreatment of $\mathrm{C} 26$ and T24 cells with a cell permeable SOD mimetic, resulted in a considerable decrease in the effectiveness of PDT with Photofrin ${ }^{\circledR}$ [254]. These results suggest that inhibition of SOD activity may be effective in potentiating the antitumor effectiveness of PDT. An up-regulation of mRNA expression of gammaglutamyl cysteine synthetase, which catalyzes the rate-limiting step in overall glutathione biosynthesis, and is subject to feedback regulation by glutathione, was also observed in the glioblastoma SNB-19 cell line sensitized with hypericin, under conditions where cell death occurred by apoptosis [256].

The effect of ALA-based PDT on the proteome was also investigated in the HL-60 promyelocytic cell line, under conditions where cell death occurred mainly by apoptosis [257]. From a total of more than 1350 protein spots obtained after separation in 2D gels, at an early stage of the demise process, the cellular content in seven proteins was increased and 17 were suppressed following sensitization. The latter group included the calreticulin precursor, p58 microsomal protein (Erp57) and protein disulfide isomerase (p55), which are all chaperones involved in calcium homeostasis. Under the same conditions Western blotting experiments showed a decrease in the amount of Erp72 and an up-regulation of calmodulin and HSP-60 [78]. Furthermore, ALA-mediated PDT in HL-60 cells decreased the expression of the anti-apoptotic proteins of the Bcl-2 family, Bcl-2 and Bcl- $\mathrm{x}_{\mathrm{L}}$, and of the pro-apoptotic protein of the same family Bax [78] (see Section 2.1.2.2 for other references). In contrast, RT-PCR analysis showed that bcl-2 is up-regulated in human ovarian carcinoma A2780 cells upon photoactivation of $\mathrm{Mce}_{6}$ (mesochlorin $\mathrm{e}_{6}$ monoethylenediamine), P-GFLGMce $_{6}$ [HPMA copolymer-Mce ${ }_{6}$ conjugate containing $\mathrm{Mce}_{6}$ bound via glycylphenylalanylleucylglycine (GFLG) linker] and NLS(FITC)GFLGMce ${ }_{6}$ [HPMA copolymer$\mathrm{Mce}_{6}$ conjugate containing $\mathrm{Mce}_{6}$ bound via glycylphenylalanylleucylglycine (GFLG) spacer and containing NLS(FITC) bound via a thioether linkage] [15]. Apoptotic death of A431 human epidermoid carcinoma cells sensitized with Pc 4 followed an increase in the protein levels of Fas and Fas ligand [39], proteins involved in the initiation of the death receptor-mediated pathway of apoptotic cell death (see Section 2.1.1).

PDT has been shown to alter the expression of TNF and IL-6. Accordingly, TNF- $\alpha$ gene transcription increased in keratinocytes sensitized with Pc 4 [258], and thioglycolateelicited murine macrophages released TNF when subjected to PDT with Photofrin II [259]. Photodynamic activation of the monocyte cell line U937 differentiated into macrophages (U937 $\Phi$ cells) with mTHPC (Foscan $\left.{ }^{\circledR}\right)$ also induced a dosedependent production of TNF- $\alpha$ [167]. However, although anti-TNF- $\alpha$ antibodies and pentoxifylline, an inhibitor of cytokine transcription, prevented cutaneous photosensitivity in adult $\mathrm{C} 3 \mathrm{H} / \mathrm{HeN}$ mice injected with $\mathrm{Pc} 4$, none of these agents affected Pc 4 PDT-induced tumor (RIF-1 radiationinduced fibrosarcoma) regression [258].

\subsection{Clusterin}

Clusterin is a glycoprotein with a nearly ubiquitous tissue distribution, but its functions remain to be understood [260]. In vitro studies showed an up-regulation of clusterin protein levels in human epidermoid carcinoma A431 cells treated with Pc 4-PDT, under conditions where cell death occurs by apoptosis, but no effect was observed in apoptosis-resistant RIF-1 cells [261]. Similarly, an increase in clusterin protein levels was observed in PDT-treated chemically induced murine skin papillomas [261], but the significance of these findings remains to be determined.

\section{6. $p 53$}

The p53 protein is present in low amounts in healthy cells, becoming up-regulated in response to various types of stress. This causes the cell to delay its entry into $\mathrm{S}$ phase until an eventual damage to DNA has been repaired. Furthermore, p53 is also involved in triggering apoptosis under circumstances in which damage is too severe to be repaired. The p53 tumor suppressor gene is mutated in over $50 \%$ of human cancers, and an important feature of the oncogenicity of these mutants is their ability to interfere with p53-dependent apoptosis [262]. The role of p53 in cell death in PDT has been addressed in two ways: (i) comparing responses to PDT of closely related human tumor cells, expressing wild-type or lacking the protein (e.g. Ref. [263]); 
(ii) comparing the clonogenical survival of normal human fibroblasts that express wild-type p53 and immortalized $\mathrm{Li}-$ Fraumeni syndrome (LFS) cells that express only mutant p53, and the LFS cells expressing wild-type p53 introduced using an adenovirus vector [264]. PDT-treated cells with various sensitizers up-regulated the expression of p53 [263265], but PDT-induced cell death or apoptosis did not show a significant dependence on $\mathrm{p} 53$.

\subsection{Interleukins}

PDT of tumors causes a rapid induction of an inflammatory response, characterized by the infiltration of leucocytes, mainly neutrophils, into the sensitized tumor $[9,174,266-$ 268]. This response is thought to be important for the activation of antitumor immunity, and in vivo studies with mammary EMT6 tumors sensitized with 2-[1-hexyloxyethyl]-2-devinyl pyropheophorbide-a (HPPH) showed that the influx of neutrophils is induced by the local up-regulation of the attractant chemokine MIP-2 (macrophage inflammatory protein, in rodents, or IL-8 in humans). Also, the upregulation in E-selectin in the tumor microvasculature increased the adhesion of EMT6 microvessels. Although there was also an increase in the neutrophil attractant chemokine $\mathrm{KC}$, it had no effect on the recruitment of neutrophils [266]. Once at the tumor site, neutrophils may cause direct tumor cell destruction, may recruit leucocytes and lymphocytes by secreting chemokines/cytokines and may be implicated in tumor rejection in T-cell-dependent reactions [269].

Photofrin-mediated photosensitization of human adenocarcinoma HeLa cells also induced rapidly the production of IL-6 mRNA, followed by secretion of the interleukin [218]. Under the same conditions AP-1 DNA binding was observed, at the distal AP-1 site of the IL-6 promoter, but not at the proximal site [218]. The mRNA for IL-6 was also changed by PDT with Photofrin in EMT6 mammary tumor cells in culture and in vivo, and a concomitant up-regulation in the interleukin protein levels was also observed in the latter model [174]. An enhanced expression of IL-6 in EMT6 tumors and an increase in the circulatory levels of IL-6 were also observed in in vivo studies, using the sensitizer HPPH [266]. The up-regulation in the IL-6 levels contrasts with the observed impairment of the response of hypopharyngeal carcinoma $\mathrm{FaDu}$ cells and of cultured human pulmonary fibroblasts to IL-6-type cytokines (IL-6, LIF and oncostatin M), observed after photosensitization with ALA or Photofrin [192] (see above). This may account for the lack of effect of IL-6 on neutrophil infiltration of EMT6 tumors, when HPPH was used as a sensitizer [266], but contrasts with the role of the cytokine on the induction of systemic neutrophilia in Photofrin-PDT [267,270].

\subsection{Regulators of angiogenesis}

Damage to the microvasculature induced by PDT produces hypoxia due to the reduction in blood flow $[2,3]$.
PDT with Photofrin ${ }^{\circledR}$ induced the expression of the hypoxia-inducible factor- $1 \alpha$ (HIF-1 $\alpha$ ) subunit of the HIF1 transcription factor complex in BA mammary carcinoma tumors growing in $\mathrm{C} 3 \mathrm{H}$ mice [271]. HIF- $1 \alpha$ associates with HIF-1 $\beta$ to form HIF-1, but whereas the latter subunit is constitutively expressed, HIF- $1 \alpha$ is rapidly degraded under normoxic conditions [272,273]. Hypoxia stabilizes HIF-1 $\alpha$, allowing the formation of the transcriptionally active HIF-1 complex, which binds to the hypoxia response element found in the promotor region of specific genes, including the vascular endothelial growth factor $(V E G F)$ gene [272,273]. Accordingly, an increase in VEGF protein levels was found in BA mammary carcinoma tumors growing in $\mathrm{C} 3 \mathrm{H}$ mice subjected to PDT with Photofrin ${ }^{\circledR}$ under conditions where cell death occurred by necrosis [271]. Oxidative stress may also lead to the overexpression of VEGF since PDT-treatment of cultured BA tumor cells also caused a slight increase in VEGF [271]. Since VEGF has a strong mitogenic activity, primarily in endothelial cells [274], studies were performed using the antiangiogenic compounds EMAP-II (single chain polypeptide) and IM862 (L-glutamyl-L-tryptophan dipeptide) to determine whether they could enhance the tumorocidal action of PDT. Both peptides decreased VEGF expression and improved tumoricidal responses in PDTtreated BA mammary carcinoma tumors growing in $\mathrm{C} 3 \mathrm{H}$ mice [271]. In this model, a synthetic inhibitor of matrix metalloproteinases (MMP), Prinomastat, also increased the percentage of long-term cures after photosensitization with Photofrin [275]. Interestingly, PDT increased the expression and activation of MMP-1, $-3,-8$ and -9 in BA tumors subjected to PDT with Photofrin, and also changed the expression of MMP regulators. In particular, there was an up-regulation in EMMPRIN levels, a protein that efficiently stimulates the production of MMPs [276], and a decrease of TIMP-1 expression, a protein that regulates the metabolism of the extracellular matrix [275,277]. Taken together, these findings indicate that a combination therapy approach, using PDT together with MMP inhibitors and/or antiangiogenic compounds, can increase the therapeutic efficacy.

\section{Conclusions}

The experimental evidences discussed throughout the manuscript show a large heterogeneity in the mechanisms leading to cell death in PDT. Although the demise process is triggered mainly by reactive oxygen species, primarily by singlet oxygen $\left({ }^{1} \mathrm{O}_{2}\right)$, it is shaped by the cell genotype, the PDT dose and the intracellular location of the sensitizer. In addition to the activation of the molecular machinery leading to cell death, PDT may also set in motion metabolic reactions that protect cells from the oxidative damage. Inhibition of the latter events is likely to potentiate the antitumor effectiveness of PDT. 


\section{Acknowledgements}

The work in the authors laboratory was supported by Fundação para a Ciência e a Tecnologia, Portugal.

\section{References}

[1] H. Takahashi, Y. Itoh, Y. Miyauchi, S. Nakajima, I. Sakata, A. Ishida-Yamamoto, H. Iizuka, Activation of two caspase cascades, caspase $8 / 3 / 6$ and caspase $9 / 3 / 6$, during photodynamic therapy using a novel photosensitizer, ATX-S10(Na), in normal human keratinocytes, Arch. Dermatol. Res. 295 (2003) 242-248.

[2] T.J. Dougherty, C.J. Gomer, B.W. Henderson, G. Jori, D. Kessel, M. Korbelik, J. Moan, Q. Peng, Photodynamic therapy, J. Natl. Cancer Inst. 90 (1998) 889-905.

[3] R. Ackroyd, C. Kelty, N. Brown, M. Reed, The history of photodetection and photodynamic therapy, Photochem. Photobiol. 74 (2001) 656-669.

[4] T.J. Dougherty, An update on photodynamic therapy applications, J. Clin. Laser Med. Surg. 20 (2002) 3-7.

[5] C.J. Gomer, Preclinical examination of first and second generation photosensitizers used in photodynamic therapy, Photochem. Photobiol. 54 (1991) $1093-1107$.

[6] G. Jori, Tumour photosensitizers: approaches to enhance the selectivity and efficiency of photodynamic therapy, J. Photochem. Photobiol., B 36 (1996) 87-93.

[7] I.J. MacDonald, T.J. Dougherty, Basic principles of photodynamic therapy, J. Porphyr. Phthalocyanines 5 (2001) 105-129.

[8] T. Reynolds, Photodynamic therapy expands its horizons, J. Natl. Cancer Inst. 89 (1997) 112-114.

[9] D.W. Hunt, A.H. Chan, Influence of photodynamic therapy on immunological aspects of disease - an update, Expert Opin. Investig. Drugs 9 (2000) 807-817.

[10] I. Rosenthal, E. Ben-Hur, Role of oxygen in the phototoxicity of phthalocyanines, Int. J. Radiat. Biol. 67 (1995) 85-91.

[11] J. Moan, K. Berg, The photodegradation of porphyrins in cells can be used to estimate the lifetime of singlet oxygen, Photochem. Photobiol. 53 (1991) $549-553$.

[12] Q. Peng, J. Moan, J.M. Nesland, Correlation of subcellular and intratumoral photosensitizer localization with ultrastructural features after photodynamic therapy, Ultrastruct. Pathol. 20 (1996) $109-129$.

[13] Y. Luo, C.K. Chang, D. Kessel, Rapid initiation of apoptosis by photodynamic therapy, Photochem. Photobiol. 63 (1996) 528-534.

[14] B.B. Noodt, K. Berg, T. Stokke, Q. Peng, J.M. Nesland, Different apoptotic pathways are induced from various intracellular sites by tetraphenylporphyrins and light, Br. J. Cancer 79 (1999) $72-81$.

[15] M. Tijerina, P. Kopeckova, J. Kopecek, Mechanisms of cytotoxicity in human ovarian carcinoma cells exposed to free $\mathrm{Mce}_{6}$ or HPMA copolymer-Mce ${ }_{6}$ conjugates, Photochem. Photobiol. 77 (2003) 645-652.

[16] D. Kessel, R. Luguya, M.G. Vicente, Localization and photodynamic efficacy of two cationic porphyrins varying in charge distribution, Photochem. Photobiol. 78 (2003) 431-435.

[17] A. Feofanov, G. Sharonov, A. Grichine, T. Karmakova, A. Pljutinskaya, V. Lebedeva, R. Ruziyev, R. Yakubovskaya, A. Mironov, M. Refregier, J.C. Maurizot, P. Vigny, Comparative study of photodynamic properties of 13,15- $\mathrm{N}$-cycloimide derivatives of chlorin p6, Photochem. Photobiol. 79 (2004) 172-188.

[18] Y. Luo, D. Kessel, Initiation of apoptosis versus necrosis by photodynamic therapy with chloroaluminum phthalocyanine, Photochem. Photobiol. 66 (1997) 479-483.

[19] E. Ben-Hur, J. Oetjen, B. Horowitz, Silicon phthalocyanine Pc 4 and red light causes apoptosis in HIV-infected cells, Photochem. Photobiol. 65 (1997) 456-460.

[20] A. Vantieghem, Z. Assefa, P. Vandenabeele, W. Declercq, S. Courtois, J.R. Vandenheede, W. Merlevede, P. de Witte, P. Agostinis, Hypericin-induced photosensitization of HeLa cells leads to apoptosis or necrosis. Involvement of cytochrome $c$ and procaspase-3 activation in the mechanism of apoptosis, FEBS Lett. 440 (1998) 19-24.

[21] S. Zhuang, M.C. Lynch, I.E. Kochevar, Caspase-8 mediates caspase3 activation and cytochrome $c$ release during singlet oxygen-induced apoptosis of HL-60 cells, Exp. Cell Res. 250 (1999) 203-212.

[22] A. Hajri, S. Coffy, F. Vallat, S. Evrard, J. Marescaux, M. Aprahamian, Human pancreatic carcinoma cells are sensitive to photodynamic therapy in vitro and in vivo, Br. J. Surg. 86 (1999) 899-906.

[23] A.R. Kamuhabwa, P.M. Agostinis, M.A. D'Hallewin, L. Baert, P.A. de Witte, Cellular photodestruction induced by hypericin in AY-27 rat bladder carcinoma cells, Photochem. Photobiol. 74 (2001) 126-132

[24] L. Wyld, M.W. Reed, N.J. Brown, Differential cell death response to photodynamic therapy is dependent on dose and cell type, Br. J. Cancer 84 (2001) 1384-1386.

[25] S.M. Ali, M. Olivo, Bio-distribution and subcellular localization of Hypericin and its role in PDT induced apoptosis in cancer cells, Int. J. Oncol. 21 (2002) 531-540.

[26] H. Jiang, D.J. Granville, J.R. North, A.M. Richter, D.W. Hunt, Selective action of the photosensitizer QLT0074 on activated human T lymphocytes, Photochem. Photobiol. 76 (2002) 224-231.

[27] K. Plaetzer, T. Kiesslich, B. Krammer, P. Hammerl, Characterization of the cell death modes and the associated changes in cellular energy supply in response to $\mathrm{AlPcS}_{4}-\mathrm{PDT}$, Photochem. Photobiol. Sci. 1 (2002) $172-177$.

[28] T. Tsai, R.L. Hong, J.C. Tsai, P.J. Lou, I.F. Ling, C.T. Chen, Effect of 5-aminolevulinic acid-mediated photodynamic therapy on MCF-7 and MCF-7/ADR cells, Lasers Surg. Med. 34 (2004) 62-72.

[29] M. Leist, P. Nicotera, The shape of cell death, Biochem. Biophys. Res. Commun. 236 (1997) 1-9.

[30] M.O. Hengartner, The biochemistry of apoptosis, Nature 407 (2000) $770-776$.

[31] D.R. Green, G.I. Evan, A matter of life and death, Cancer Cell 1 (2002) 19-30.

[32] A. Lawen, Apoptosis - an introduction, Bioessays 25 (2003) $888-896$.

[33] D. Wallach, E.E. Varfolomeev, N.L. Malinin, Y.V. Goltsev, A.V. Kovalenko, M.P. Boldin, Tumor necrosis factor receptor and Fas signaling mechanisms, Annu. Rev. Immunol. 17 (1999) 331-367.

[34] X. Liu, C.N. Kim, J. Yang, R. Jemmerson, X. Wang, Induction of apoptotic program in cell-free extracts: requirement for dATP and cytochrome $c$, Cell 86 (1996) 147-157.

[35] H. Zou, Y. Li, X. Liu, X. Wang, An APAF-1-cytochrome $c$ multimeric complex is a functional apoptosome that activates procaspase9, J. Biol. Chem. 274 (1999) 11549-11556.

[36] K. Lauber, H.A. Appel, S.F. Schlosser, M. Gregor, K. SchulzeOsthoff, S. Wesselborg, The adapter protein apoptotic proteaseactivating factor-1 (Apaf-1) is proteolytically processed during apoptosis, J. Biol. Chem. 276 (2001) 29772-29781.

[37] J.M. Adams, S. Cory, Apoptosomes: engines for caspase activation, Curr. Opin. Cell Biol. 14 (2002) 715-720.

[38] R.J. Krieser, K. White, Engulfment mechanism of apoptotic cells, Curr. Opin. Cell Biol. 14 (2002) 734-738.

[39] N. Ahmad, S. Gupta, D.K. Feyes, H. Mukhtar, Involvement of Fas (APO-1/CD-95) during photodynamic-therapy-mediated apoptosis in human epidermoid carcinoma A431cells, J. Invest. Dermatol. 115 (2000) $1041-1046$

[40] S.M. Ali, S.K. Chee, G.Y. Yuen, M. Olivo, Photodynamic therapy induced Fas-mediated apoptosis in human carcinoma cells, Int. J. Mol. Med. 9 (2002) 257-270.

[41] T. Yokota, H. Ikeda, T. Inokuchi, K. Sano, T. Koji, Enhanced cell death in NR-S1 tumor by photodynamic therapy: possible involve- 
ment of Fas and Fas ligand system, Lasers Surg. Med. 26 (2000) $449-460$.

[42] J. Dahle, O. Kaalhus, J. Moan, H.B. Steen, Cooperative effects of photodynamic treatment of cells in microcolonies, Proc. Natl. Acad. Sci. U. S. A. 94 (1997) 1773-1778.

[43] K.H. Tan, W. Hunziker, Compartmentalization of Fas and Fas ligand may prevent auto-or paracrine apoptosis in epithelial cells, Exp. Cell Res. 284 (2003) 283-290.

[44] S. Zhuang, J.T. Demirs, I.E. Kochevar, p38 Mitogen-activated protein kinase mediates Bid cleavage, mitochondrial dysfunction, and caspase-3 activation during apoptosis induced by singlet oxygen but not by hydrogen peroxide, J. Biol. Chem. 275 (2000) 25939-25948.

[45] B. Antonsson, J.C. Martinou, The Bcl-2 protein family, Exp. Cell Res. 256 (2000) 50-57.

[46] M.H. Harris, C.B. Thompson, The role of the Bcl-2 family in the regulation of outer mitochondrial membrane permeability, Cell Death Differ. 7 (2000) 1182-1191.

[47] S. Cory, J.M. Adams, The Bcl2 family: regulators of the cellular lifeor-death switch, Nat. Rev. Cancer 2 (2002) 647-656.

[48] S. Zhuang, I.E. Kochevar, Ultraviolet A radiation induces rapid apoptosis of human leukemia cells by Fas ligand-independent activation of the Fas death pathways, Photochem. Photobiol. 78 (2003) 61-67.

[49] B. Nagy, W.C. Yeh, T.W. Mak, S.M. Chiu, D. Separovic, FADD null mouse embryonic fibroblasts undergo apoptosis after photosensitization with the silicon phthalocyanine Pc 4, Arch. Biochem. Biophys. 385 (2001) 194-202.

[50] R.S. Murant, S.L. Gibson, R. Hilf, Photosensitizing effects of Photofrin II on the site selected mitochondrial enzymes adenylate kinase and monoamine oxidase, Cancer Res. 47 (1987) 4323-4328.

[51] K.W. Woodburn, N.J. Vardaxis, J.S. Hill, A.H. Kaye, D.R. Phillips, Subcellular localization of porphyrins using confocal laser scanning microscopy, Photochem. Photobiol. 54 (1991) 725-732.

[52] F. Ricchelli, S. Gobbo, G. Jori, C. Salet, G. Moreno, Temperatureinduced changes in fluorescence properties as a probe of porphyrin microenvironment in lipid membranes: 2. The partition of hematoporphyrin and protoporphyrin in mitochondria, Eur. J. Biochem. 233 (1995) $165-170$.

[53] R.M. Szeimies, S. Karrer, C. Abels, P. Steinbach, S. Fickweiler, H. Messmann, W. Baumler, M. Landthaler, 9-Acetoxy-2,7,12,17tetrakis-(beta-methoxyethyl)-porphycene (ATMPn), a novel photosensitizer for photodynamic therapy: uptake kinetics and intracellular localization, J. Photochem. Photobiol, B. 34 (1996) 67-72.

[54] M. Lam, N.L. Oleinick, A.L. Nieminen, Photodynamic therapy-induced apoptosis in epidermoid carcinoma cells. Reactive oxygen species and mitochondrial inner membrane permeabilization, J. Biol. Chem. 276 (2001) 47379-47386.

[55] J. Usuda, S.M. Chiu, E.S. Murphy, M. Lam, A.L. Nieminen, N.L. Oleinick, Domain dependent photodamage to Bcl-2. A membrane anchorage region is needed to form the target of phthalocyanine photosensitization, J. Biol. Chem. 278 (2003) 2021-2029.

[56] A. Graham, G. Li, Y. Chen, J. Morgan, A. Oseroff, T.J. Dougherty, R.K. Pandey, Structure-activity relationship of new octaethylporphyrin-based benzochlorins as photosensitizers for photodynamic therapy, Photochem. Photobiol. 77 (2003) 561-566.

[57] D.D. Newmeyer, S. Ferguson-Miller, Mitochondria: releasing power for life and unleashing the machineries of death, Cell 112 (2003) $481-490$.

[58] D. Kessel, Y. Luo, Y. Deng, C.K. Chang, The role of subcellular localization in initiation of apoptosis by photodynamic therapy, Photochem. Photobiol. 65 (1997) 422-426.

[59] D. Kessel, M. Castelli, Evidence that bcl-2 is the target of three photosensitizers that induce a rapid apoptotic response, Photochem. Photobiol. 74 (2001) 318-322.

[60] J.J. Reiners Jr., J.A. Caruso, P. Mathieu, B. Chelladurai, X.M. Yin, D. Kessel, Release of cytochrome $c$ and activation of pro-caspase-9 following lysosomal photo damage involves Bid cleavage, Cell Death Differ. 9 (2002) 934-944.

[61] M.H. Teiten, S. Marchal, M.A. D'Hallewin, F. Guillemin, L. Bezdetnaya, Primary photodamage sites and mitochondrial events after Foscan photosensitization of MCF-7 human breast cancer cells, Photochem. Photobiol. 78 (2003) 9-14.

[62] M.H. Teiten, L. Bezdetnaya, P. Morliere, R. Santus, F. Guillemin, Endoplasmic reticulum and Golgi apparatus are the preferential sites of Foscan localisation in cultured tumour cells, Br. J. Cancer 88 (2003) $146-152$.

[63] O. Inanami, A. Yoshito, K. Takahashi, W. Hiraoka, M. Kuwabara, Effects of BAPTA-AM and forskolin on apoptosis and cytochrome $c$ release in photosensitized Chinese hamster V79 cells, Photochem. Photobiol. 70 (1999) 650-655.

[64] M.E. Varnes, S.M. Chiu, L.Y. Xue, N.L. Oleinick, Photodynamic therapy-induced apoptosis in lymphoma cells: translocation of cytochrome $c$ causes inhibition of respiration as well as caspase activation, Biochem. Biophys. Res. Commun. 255 (1999) 673-679.

[65] V. Carre, C. Jayat, R. Granet, P. Krausz, M. Guilloton, Chronology of the apoptotic events induced in the K562 cell line by photodynamic treatment with hematoporphyrin and monoglucosylporphyrin, Photochem. Photobiol. 69 (1999) 55-60.

[66] C.B. Oberdanner, T. Kiesslich, B. Krammer, K. Plaetzer, Glucose is required to maintain high ATP-levels for the energy-utilizing steps during PDT-induced apoptosis, Photochem. Photobiol. 76 (2002) $695-703$.

[67] D. Kessel, Y. Luo, Photodynamic therapy: a mitochondrial inducer of apoptosis, Cell Death Differ. 6 (1999) 28-35.

[68] A. Vantieghem, Y. Xu, W. Declercq, P. Vandenabeele, G. Denecker, J.R. Vandenheede, W. Merlevede, P.A. de Witte, P. Agostinis, Different pathways mediate cytochrome $c$ release after photodynamic therapy with hypericin, Photochem. Photobiol. 74 (2001) 133-142.

[69] R. Chaloupka, P.X. Petit, N. Israel, F. Sureau, Over-expression of Bcl-2 does not protect cells from hypericin photo-induced mitochondrial membrane depolarization, but delays subsequent events in the apoptotic pathway, FEBS Lett. 462 (1999) 295-301.

[70] S. Chiu, H.H. Evans, M. Lam, A. Nieminen, N.L. Oleinick, Phthalocyanine 4 photodynamic therapy-induced apoptosis of mouse L5178Y-R cells results from a delayed but extensive release of cytochrome $c$ from mitochondria, Cancer Lett. 165 (2001) 51-58.

[71] D.J. Granville, C.M. Carthy, H. Jiang, G.C. Shore, B.M. McManus, D.W. Hunt, Rapid cytochrome $c$ release, activation of caspases 3, 6 , 7 and 8 followed by Bap31 cleavage in HeLa cells treated with photodynamic therapy, FEBS Lett. 437 (1998) 5-10.

[72] D.J. Granville, J.R. Shaw, S. Leong, C.M. Carthy, P. Margaron, D.W. Hunt, B.M. McManus, Release of cytochrome $c$, Bax migration, Bid cleavage, and activation of caspases 2, 3, 6, 7, 8, and 9 during endothelial cell apoptosis, Am. J. Pathol. 155 (1999) 1021-1025.

[73] C.M. Carthy, D.J. Granville, H. Jiang, J.G. Levy, C.M. Rudin, C.B. Thompson, B.M. McManus, D.W. Hunt, Early release of mitochondrial cytochrome $c$ and expression of mitochondrial epitope 7A6 with a porphyrin-derived photosensitizer: Bcl-2 and Bcl- $\mathrm{x}_{\mathrm{L}}$ overexpression do not prevent early mitochondrial events but still depress caspase activity, Lab. Invest. 79 (1999) 953-965.

[74] E.A. Slee, S.A. Keogh, S.J. Martin, Cleavage of BID during cytotoxic drug and UV radiation-induced apoptosis occurs downstream of the point of Bcl-2 action and is catalysed by caspase-3: a potential feedback loop for amplification of apoptosis-associated mitochondrial cytochrome $c$ release, Cell Death Differ. 7 (2000) 556-565.

[75] D.J. Granville, J.G. Levy, D.W. Hunt, Photodynamic therapy induces caspase-3 activation in HL-60 cells, Cell Death Differ. 4 (1997) $623-628$.

[76] D.J. Granville, H. Jiang, M.T. An, J.G. Levy, B.M. McManus, D.W. Hunt, Overexpression of Bcl-X(L) prevents caspase-3-mediated activation of DNA fragmentation factor (DFF) produced by treatment with the photochemotherapeutic agent BPD-MA, FEBS Lett. 422 (1998) $151-154$. 
[77] D.J. Granville, H. Jiang, M.T. An, J.G. Levy, B.M. McManus, D.W. Hunt, Bcl-2 overexpression blocks caspase activation and downstream apoptotic events instigated by photodynamic therapy, Br. J. Cancer 79 (1999) 95-100.

[78] D. Grebenova, K. Kuzelova, K. Smetana, M. Pluskalova, H. Cajthamlova, I. Marinov, O. Fuchs, J. Soucek, P. Jarolim, Z. Hrkal, Mitochondrial and endoplasmic reticulum stress-induced apoptotic pathways are activated by 5 -aminolevulinic acid-based photodynamic therapy in HL60 leukemia cells, J. Photochem. Photobiol., B 69 (2003) $71-85$.

[79] D.J. Granville, C.M. Carthy, H. Jiang, J.G. Levy, B.M. McManus, J.Y. Matroule, J. Piette, D.W. Hunt, Nuclear factor-kappaB activation by the photochemotherapeutic agent verteporfin, Blood 95 (2000) 256-262.

[80] Z. Assefa, A. Vantieghem, W. Declercq, P. Vandenabeele, J.R. Vandenheede, W. Merlevede, P. de Witte, P. Agostinis, The activation of the c-Jun N-terminal kinase and p38 mitogen-activated protein kinase signaling pathways protects $\mathrm{HeLa}$ cells from apoptosis following photodynamic therapy with hypericin, J. Biol. Chem. 274 (1999) 8788-8796.

[81] A. Vantieghem, Y. Xu, Z. Assefa, J. Piette, J.R. Vandenheede, W. Merlevede, P.A.M. de Witte, P. Agostinis, Phosphorylation of BCL-2 in $\mathrm{G}_{2} / \mathrm{M}$ phase arrested cells following photodynamic therapy with hypericin involves a CDK1-mediated signal and delays the onset of apoptosis, J. Biol. Chem. (2002) M204348200.

[82] N. Ahmad, K. Kalka, H. Mukhtar, In vitro and in vivo inhibition of epidermal growth factor receptor-tyrosine kinase pathway by photodynamic therapy, Oncogene 20 (2001) 2314-2317.

[83] J. He, C.M. Whitacre, L.Y. Xue, N.A. Berger, N.L. Oleinick, Protease activation and cleavage of poly(ADP-ribose) polymerase: an integral part of apoptosis in response to photodynamic treatment, Cancer Res. 58 (1998) 940-946.

[84] L.Y. Xue, Y. Qiu, J. He, H.J. Kung, N.L. Oleinick, Etk/Bmx, a PHdomain containing tyrosine kinase, protects prostate cancer cells from apoptosis induced by photodynamic therapy or thapsigargin, Oncogene 18 (1999) 3391-3398.

[85] B. Wispriyono, E. Schmelz, H. Pelayo, K. Hanada, D. Separovic, A role for the de novo sphingolipids in apoptosis of photosensitized cells, Exp. Cell Res. 279 (2002) 153-165.

[86] M.F. Counis, A. Torriglia, DNases and apoptosis, Biochem. Cell. Biol. 78 (2000) 405-414.

[87] M. Ogata, O. Inanami, M. Nakajima, T. Nakajima, W. Hiraoka, M. Kuwabara, $\mathrm{Ca}^{2+}$-dependent and caspase-3-independent apoptosis caused by damage in Golgi apparatus due to 2,4,5,7-tetrabromorhodamine 123 bromide-induced photodynamic effects, Photochem. Photobiol. 78 (2003) 241-247.

[88] L.Y. Xue, S.M. Chiu, N.L. Oleinick, Photodynamic therapy-induced death of MCF-7 human breast cancer cells: a role for caspase-3 in the late steps of apoptosis but not for the critical lethal event, Exp. Cell Res. 263 (2001) 145-155.

[89] C.M. Whitacre, T.H. Satoh, L. Xue, N.H. Gordon, N.L. Oleinick, Photodynamic therapy of human breast cancer xenografts lacking caspase-3, Cancer Lett. 179 (2002) 43-49.

[90] X.M. Sun, S.B. Bratton, M. Butterworth, M. MacFarlane, G.M. Cohen, Bcl-2 and $\mathrm{Bcl}-\mathrm{x}_{\mathrm{L}}$ inhibit $\mathrm{CD} 95$-mediated apoptosis by preventing mitochondrial release of Smac/DIABLO and subsequent inactivation of $\mathrm{X}$-linked inhibitor-of-apoptosis protein, $\mathrm{J}$. Biol. Chem. 277 (2002) 11345-11351.

[91] J. He, M.L. Agarwal, H.E. Larkin, L.R. Friedman, L.Y. Xue, N.L. Oleinick, The induction of partial resistance to photodynamic therapy by the protooncogene BCL-2, Photochem. Photobiol. 64 (1996) 845-852.

[92] W.G. Zhang, L.P. Ma, S.W. Wang, Z.Y. Zhang, G.D. Cao, Antisense bcl-2 retrovirus vector increases the sensitivity of a human gastric adenocarcinoma cell line to photodynamic therapy, Photochem. Photobiol. 69 (1999) $582-586$.

[93] M. Srivastava, N. Ahmad, S. Gupta, H. Mukhtar, Involvement of
Bcl-2 and Bax in photodynamic therapy-mediated apoptosis. Antisense Bcl-2 oligonucleotide sensitizes RIF1 cells to photodynamic therapy apoptosis, J. Biol. Chem. 276 (2001) 15481-15488.

[94] H.R. Kim, Y. Luo, G. Li, D. Kessel, Enhanced apoptotic response to photodynamic therapy after bcl-2 transfection, Cancer Res. 59 (1999) 3429-3432.

[95] L.Y. Xue, S.M. Chiu, A. Fiebig, D.W. Andrews, N.L. Oleinick, Photodamage to multiple $\mathrm{Bcl}-\mathrm{x}_{\mathrm{L}}$ isoforms by photodynamic therapy with the phthalocyanine photosensitizer Pc 4, Oncogene 22 (2003) 9197-9204.

[96] D. Kessel, M. Castelli, J.J. Reiners Jr., Apoptotic response to photodynamic therapy versus the Bcl-2 antagonist HA14-1, Photochem. Photobiol. 76 (2002) 314-319.

[97] L.Y. Xue, S.M. Chiu, N.L. Oleinick, Photochemical destruction of the Bcl-2 oncoprotein during photodynamic therapy with the phthalocyanine photosensitizer Pc 4, Oncogene 20 (2001) $3420-3427$

[98] J. Usuda, K. Azizuddin, S.M. Chiu, N.L. Oleinick, Association between the photodynamic loss of Bcl-2 and the sensitivity to apoptosis caused by phthalocyanine photodynamic therapy, Photochem. Photobiol. 78 (2003) 1-8.

[99] J. Usuda, S.M. Chiu, K. Azizuddin, L.Y. Xue, M. Lam, A.L. Nieminen, N.L. Oleinick, Promotion of photodynamic therapy-induced apoptosis by the mitochondrial protein Smac/DIABLO: dependence on Bax, Photochem. Photobiol. 76 (2002) 217-223.

[100] S.M. Chiu, L.Y. Xue, J. Usuda, K. Azizuddin, N.L. Oleinick, Bax is essential for mitochondrion-mediated apoptosis but not for cell death caused by photodynamic therapy, Br. J. Cancer 89 (2003) $1590-1597$.

[101] C. Du, M. Fang, Y. Li, L. Li, X. Wang, Smac, a mitochondrial protein that promotescytochrome $c$-dependent caspase activation by eliminating IAP inhibition, Cell 102 (2000) 33-42.

[102] A.M. Verhagen, P.G. Ekert, M. Pakusch, J. Silke, L.M. Connolly, G.E. Reid, R.L. Moritz, R.J. Simpson, D.L. Vaux, Identification of DIABLO, a mammalian protein that promotes apoptosis by binding to and antagonizing IAP proteins, Cell 102 (2000) 43-53.

[103] H. Tajiri, A. Hayakawa, Y. Matsumoto, I. Yokoyama, S. Yoshida, Changes in intracellular $\mathrm{Ca}^{2+}$ concentrations related to PDT-induced apoptosis in photosensitized human cancer cells, Cancer Lett. 128 (1998) 205-210.

[104] A. Hubmer, A. Hermann, K. Uberriegler, B. Krammer, Role of calcium in photodynamically induced cell damage of human fibroblasts, Photochem. Photobiol. 64 (1996) 211-215.

[105] O.A. Gederaas, K. Thorstensen, I. Romslo, The effect of brief illumination on intracellular free calcium concentration in cells with 5aminolevulinic acid-induced protoporphyrin IX synthesis, Scand. J. Clin. Lab. Invest. 56 (1996) 583-589.

[106] Z.J. Cui, Y. Habara, D.Y. Wang, T. Kanno, A novel aspect of photodynamic action: induction of recurrent spikes in cytosolic calcium concentration, Photochem. Photobiol. 65 (1997) 382-386.

[107] Z.J. Cui, T. Kanno, Photodynamic triggering of calcium oscillation in the isolated rat pancreatic acini, J. Physiol. 504 (1997) 47-55.

[108] L.C. Penning, M.H. Rasch, E. Ben-Hur, T.M. Dubbelman, A.C. Havelaar, J. Van der Zee, J. Van Steveninck, A role for the transient increase of cytoplasmic free calcium in cell rescue after photodynamic treatment, Biochim. Biophys. Acta 1107 (1992) 255-260.

[109] L.C. Penning, J.W. Lagerberg, J.H. VanDierendonck, C.J. Cornelisse, T.M. Dubbelman, J. VanSteveninck, The role of DNA damage and inhibition of poly(ADP-ribosyl)ation in loss of clonogenicity of murine L929 fibroblasts, caused by photodynamically induced oxidative stress, Cancer Res. 54 (1994) 5561-5567.

[110] E. Ben-Hur, T.M. Dubbelman, J. Van Steveninck, Phthalocyanineinduced photodynamic changes of cytoplasmic free calcium in Chinese hamster cells, Photochem. Photobiol. 54 (1991) 163-166.

[111] K.G. Specht, M.A. Rodgers, Plasma membrane depolarization and calcium influx during cell injury by photodynamic action, Biochim. Biophys. Acta 1070 (1991) 60-68. 
[112] D.J. Granville, D.O. Ruehlmann, J.C. Choy, B.A. Cassidy, D.W. Hunt, van Breemen, C. van Breemen, B.M. McManus, Bcl-2 increases emptying of endoplasmic reticulum $\mathrm{Ca}^{2+}$ stores during photodynamic therapy-induced apoptosis, Cell Calcium 30 (2001) 343-350.

[113] A. Ruck, K. Heckelsmiller, R. Kaufmann, N. Grossman, E. Haseroth, N. Akgun, Light-induced apoptosis involves a defined sequence of cytoplasmic and nuclear calcium release in $\mathrm{AlPcS}_{4}$-photosensitized rat bladder RR 1022 epithelial cells, Photochem. Photobiol. 72 (2000) $210-216$.

[114] E. Ben-Her, T.M. Dubbelman, Cytoplasmic free calcium changes as a trigger mechanism in the response of cells to photosensitization, Photochem. Photobiol. 58 (1993) 890-894.

[115] G. Yonuschot, Early increase in intracellular calcium during photodynamic permeabilization, Free Radic. Biol. Med. 11 (1991) 307-317.

[116] P.G. Joshi, K. Joshi, S. Mishra, N.B. Joshi, $\mathrm{Ca}^{2+}$ influx induced by photodynamic action in human cerebral glioma (U-87 MG) cells: possible involvement of a calcium channel, Photochem. Photobiol. 60 (1994) 244-248.

[117] Y.P. An, R. Xiao, H. Cui, Z.J. Cui, Selective activation by photodynamic action of cholecystokinin receptor in the freshly isolated rat pancreatic acini, Br. J. Pharmacol. 139 (2003) 872-880.

[118] D.I. Marks, R.M. Fox, Mechanisms of photochemotherapy-induced apoptotic cell death in lymphoid cells, Biochem. Cell. Biol. 69 (1991) $754-760$.

[119] L.C. Penning, M.J. Keirse, J. VanSteveninck, T.M. Dubbelman, $\mathrm{Ca}^{2+}$-mediated prostaglandin $\mathrm{E}_{2}$ induction reduces haematoporphyrin-derivative-induced cytotoxicity of T24 human bladder transitional carcinoma cells in vitro, Biochem. J. 292 (1993) 237-240.

[120] M.L. Agarwal, H.E. Larkin, S.I. Zaidi, H. Mukhtar, N.L. Oleinick, Phospholipase activation triggers apoptosis in photosensitized mouse lymphoma cells, Cancer Res. 53 (1993) 5897-5902.

[121] F. Ricchelli, P. Barbato, M. Milani, S. Gobbo, C. Salet, G. Moreno, Photodynamic action of porphyrin on $\mathrm{Ca}^{2+}$ influx in endoplasmic reticulum: a comparison with mitochondria, Biochem. J. 338 (1999) $221-227$.

[122] T. Pozzan, R. Rizzuto, P. Volpe, J. Meldolesi, Molecular and cellular physiology of intracellular calcium stores, Physiol. Rev. 74 (1994) 595-636.

[123] G.A. Moore, D.J. McConkey, G.E. Kass, P.J. O’Brien, S. Orrenius, 2,5-Di(tert-butyl)-1,4-benzohydroquinone-a novel inhibitor of liver microsomal $\mathrm{Ca}^{2+}$ sequestration, FEBS Lett. 224 (1987) 331-336.

[124] O. Thastrup, P.J. Cullen, B.K. Drobak, M.R. Hanley, A.P. Dawson, Thapsigargin, a tumor promoter, discharges intracellular $\mathrm{Ca}^{2+}$ stores by specific inhibition of the endoplasmic reticulum $\mathrm{Ca}^{2+}$-ATPase, Proc. Natl. Acad. Sci. U. S. A. 87 (1990) 2466-2470.

[125] C.B. Duarte, P.F. Santos, A.P. Carvalho, $\left[\mathrm{Ca}^{2+}\right]_{\mathrm{i}}$ regulation by glutamate receptor agonists in cultured chick retina cells, Vis. Res. 36 (1996) 1091-1102.

[126] T. Nakagawa, H. Zhu, N. Morishima, E. Li, J. Xu, B.A. Yankner, J. Yuan, Caspase-12 mediates endoplasmic-reticulum-specific apoptosis and cytotoxicity by amyloid-beta, Nature 403 (2000) 98-103.

[127] R.V. Rao, S. Castro-Obregon, H. Frankowski, M. Schuler, V. Stoka, G. del Rio, D.E. Bredesen, H.M. Ellerby, Coupling endoplasmic reticulum stress to the cell death program. An Apaf-1-independent intrinsic pathway, J. Biol. Chem. 277 (2002) 21836-21842.

[128] T. Nakagawa, J. Yuan, Cross-talk between two cysteine protease families. Activation of caspase-12 by calpain in apoptosis, J. Cell Biol. 150 (2000) 887-894.

[129] R.V. Rao, E. Hermel, S. Castro-Obregon, G. del Rio, L.M. Ellerby, H.M. Ellerby, D.E. Bredesen, Coupling endoplasmic reticulum stress to the cell death program. Mechanism of caspase activation, J. Biol. Chem. 276 (2001) 33869-33874.

[130] B.L. Schwab, D. Guerini, C. Didszun, D. Bano, E. Ferrando-May, E. Fava, J. Tam, D. Xu, S. Xanthoudakis, D.W. Nicholson, E. Carafoli, P. Nicotera, Cleavage of plasma membrane calcium pumps by caspases: a link between apoptosis and necrosis, Cell Death Differ. 9 (2002) $818-831$.
[131] D.A. Eberhard, R.W. Holz, Intracellular $\mathrm{Ca}^{2+}$ activates phospholipase C, Trends Neurosci. 11 (1988) 517-520.

[132] M.J. Berridge, Inositol trisphosphate and calcium signalling, Nature 361 (1993) 315-325.

[133] G.M. Bokoch, Caspase-mediated activation of PAK2 during apoptosis: proteolytic kinase activation as a general mechanism of apoptotic signal transduction? Cell Death Differ. 5 (1998) 637-645.

[134] T.G. Cross, D. Scheel-Toellner, N.V. Henriquez, E. Deacon, M. Salmon, J.M. Lord, Serine/threonine protein kinases and apoptosis, Exp. Cell Res. 256 (2000) 34-41.

[135] M.H. Rasch, K. Tijssen, J.W. Lagerberg, W.E. Corver, J. VanSteveninck, T.M. Dubbelman, The role of protein kinase C activity in the killing of Chinese hamster ovary cells by ionizing radiation and photodynamic treatment, Photochem. Photobiol. 66 (1997) 209-213.

[136] B.W. Henderson, J.M. Donovan, Release of prostaglandin $\mathrm{E}_{2}$ from cells by photodynamic treatment in vitro, Cancer Res. 49 (1989) 6896-6900.

[137] B.W. Henderson, B. Owczarczak, J. Sweeney, T. Gessner, Effects of photodynamic treatment of platelets or endothelial cells in vitro on platelet aggregation, Photochem. Photobiol. 56 (1992) 513-521.

[138] M. al-Laith, E.K. Matthews, Z.J. Cui, Photodynamic drug action on isolated rat pancreatic acini. Mobilization of arachidonic acid and prostaglandin production, Biochem. Pharmacol. 46 (1993) $567-573$

[139] V.H. Fingar, T.J. Wieman, P.S. Karavolos, K.W. Doak, R. Ouellet, J.E. van Lier, The effects of photodynamic therapy using differently substituted zinc phthalocyanines on vessel constriction, vessel leakage and tumor response, Photochem. Photobiol. 58 (1993) 251-258.

[140] C.B. Duarte, P.F. Santos, J. Sanchez-Prieto, A.P. Carvalho, Glutamate release evoked by glutamate receptor agonists in cultured chick retina cells: modulation by arachidonic acid, J. Neurosci. Res. 44 (1996) 363-373.

[141] J. Balsinde, M.A. Balboa, P.A. Insel, E.A. Dennis, Regulation and inhibition of phospholipase $\mathrm{A}_{2}$, Annu. Rev. Pharmacol. Toxicol. 39 (1999) $175-189$.

[142] J.F. Dixon, L.E. Hokin, Secretogogue-stimulated phosphatidylinositol breakdown in the exocrine pancreas liberates arachidonic acid, stearic acid, and glycerol by sequential actions of phospholipase C and diglyceride lipase, J. Biol. Chem. 259 (1984) 14418-14425.

[143] M.T. Foultier, T. Patrice, S. Yactayo, Y. Lajat, F. Resche, Photodynamic treatment of normal endothelial cells or glioma cells in vitro, Surg. Neurol. 37 (1992) 83-88.

[144] A. Ferrario, K. Von Tiehl, S. Wong, M. Luna, C.J. Gomer, Cyclooxygenase-2 inhibitor treatment enhances photodynamic therapymediated tumor response, Cancer Res. 62 (2002) 3956-3961.

[145] N. Hendrickx, C. Volanti, U. Moens, O.M. Seternes, P. De Witte, J.R. Vandenheede, J. Piette, P. Agostinis, Up-regulation of cyclooxygenase-2 and apoptosis resistance by 38 MAPK in hypericinmediated photodynamic therapy of human cancer cells, J. Biol. Chem. 278 (2003) 52231-52239.

[146] J.D. Morrow, T.M. Harris, L.J. Roberts 2nd, Noncyclooxygenase oxidative formation of a series of novel prostaglandins: analytical ramifications for measurement of eicosanoids, Anal. Biochem. 184 (1990) 1-10.

[147] V.H. Fingar, T.J. Wieman, K.W. Doak, Role of thromboxane and prostacyclin release on photodynamic therapy-induced tumor destruction, Cancer Res. 50 (1990) 2599-2603.

[148] V.H. Fingar, T.J. Wieman, K.W. Doak, Mechanistic studies of PDTinduced vascular damage: evidence that eicosanoids mediate this process, Int. J. Radiat. Biol. 60 (1991) 303-309.

[149] V.H. Fingar, T.J. Wieman, S.A. Wiehle, P.B. Cerrito, The role of microvascular damage in photodynamic therapy: the effect of treatment on vessel constriction, permeability, and leukocyte adhesion, Cancer Res. 52 (1992) 4914-4921.

[150] V.H. Fingar, K.A. Siegel, T.J. Wieman, K.W. Doak, The effects of thromboxane inhibitors on the microvascular and tumor re- 
sponse to photodynamic therapy, Photochem. Photobiol. 58 (1993) 393-399.

[151] S. Mathias, L.A. Pena, R.N. Kolesnick, Signal transduction of stress via ceramide, Biochem. J. 335 (1998) 465-480.

[152] N. Andrieu-Abadie, V. Gouaze, R. Salvayre, T. Levade, Ceramide in apoptosis signaling: relationship with oxidative stress, Free Radic. Biol. Med. 31 (2001) 717-728.

[153] Y.A. Hannun, C. Luberto, K.M. Argraves, Enzymes of sphingolipid metabolism: from modular to integrative signaling, Biochemistry 40 (2001) 4893-4903.

[154] D. Separovic, J. He, N.L. Oleinick, Ceramide generation in response to photodynamic treatment of L5178Y mouse lymphoma cells, Cancer Res. 57 (1997) 1717-1721.

[155] D. Separovic, K.J. Mann, N.L. Oleinick, Association of ceramide accumulation with photodynamic treatment-induced cell death, Photochem. Photobiol. 68 (1998) 101-109.

[156] D. Separovic, J.J. Pink, N.A. Oleinick, M. Kester, D.A. Boothman, M. McLoughlin, L.A. Pena, A. Haimovitz-Friedman, NiemannPick human lymphoblasts are resistant to phthalocyanine 4-photodynamic therapy-induced apoptosis, Biochem. Biophys. Res. Commun. 258 (1999) 506-512.

[157] S.M. Chiu, T.W. Davis, M. Meyers, N. Ahmad, H. Mukhtar, D. Separovic, Phthalocyanine 4-photodynamic therapy induces ceramide generation and apoptosis in acid sphingomyelinase-deficient mouse embryonic fibroblasts, Int. J. Oncol. 16 (2000) 423-427.

[158] B. Nagy, S.M. Chiu, D. Separovic, Fumonisin B1 does not prevent apoptosis in A431 human epidermoid carcinoma cells after photosensitization with a silicon phthalocyanine, J. Photochem. Photobiol., B 57 (2000) 132-141.

[159] V. Dolgachev, M.S. Farooqui, O.I. Kulaeva, M.A. Tainsky, B. Nagy, K. Hanada, D. Separovic, De novo ceramide accumulation due to inhibition of its conversion to complex sphingolipids in apoptotic photosensitized cells, J. Biol. Chem. 279 (2004) 23238-23249.

[160] J.Y. Matroule, G. Bonizzi, P. Morliere, N. Paillous, R. Santus, V. Bours, J. Piette, Pyropheophorbide-a methyl ester-mediated photosensitization activates transcription factor NF-kappaB through the interleukin-1 receptor-dependent signaling pathway, J. Biol. Chem. 274 (1999) 2988-3000.

[161] V. Dolgachev, B. Nagy, B. Taffe, K. Hanada, D. Separovic, Reactive oxygen species generation is independent of de novo sphingolipids in apoptotic photosensitized cells, Exp. Cell Res. 288 (2003) $425-436$.

[162] E. Coroneos, Y. Wang, J.R. Panuska, D.J. Templeton, M. Kester, Sphingolipid metabolites differentially regulate extracellular signalregulated kinase and stress-activated protein kinase cascades, Biochem. J. 316 (1996) 13-17.

[163] M. Verheij, R. Bose, X.H. Lin, B. Yao, W.D. Jarvis, S. Grant, M.J. Birrer, E. Szabo, L.I. Zon, J.M. Kyriakis, A. Haimovitz-Friedman, Z. Fuks, R.N. Kolesnick, Requirement for ceramide-initiated SAPK/JNK signalling in stress-induced apoptosis, Nature 380 (1996) $75-79$.

[164] L.C. Penning, J. VanSteveninck, T.M. Dubbelman, HPD-induced photodynamic changes in intracellular cyclic AMP levels in human bladder transitional carcinoma cells, clone T24, Biochem. Biophys. Res. Commun. 194 (1993) 1084-1089.

[165] L.C. Jadeski, K.O. Hum, C. Chakraborty, P.K. Lala, Nitric oxide promotes murine mammary tumour growth and metastasis by stimulating tumour cell migration, invasiveness and angiogenesis, Int. J. Cancer 86 (2000) 30-39.

[166] G.M. Tozer, V.E. Prise, D.J. Chaplin, Inhibition of nitric oxide synthase induces a selective reduction in tumor blood flow that is reversible with L-arginine, Cancer Res. 57 (1997) 948-955.

[167] S. Coutier, L. Bezdetnaya, S. Marchal, V. Melnikova, I. Belitchenko, J.L. Merlin, F. Guillemin, Foscan (mTHPC) photosensitized macrophage activation: enhancement of phagocytosis, nitric oxide release and tumour necrosis factor-alpha-mediated cytolytic activity, Br. J. Cancer 81 (1999) 37-42.
[168] S.M. Ali, M. Olivo, Nitric oxide mediated photo-induced cell death in human malignant cells, Int. J. Oncol. 22 (2003) 751-756.

[169] T. Dalbasti, S. Cagli, E. Kilinc, N. Oktar, M. Ozsoz, Online electrochemical monitoring of nitric oxide during photodynamic therapy, Nitric Oxide 7 (2002) 301-305.

[170] U. Förstermann, Regulation of nitric oxide synthase expression and activity, in: B. Mayer (Ed.), Handbook of Experimental Pharmacology, Springer-Verlag, Berlin, 2000, pp. 71-91.

[171] W.M. Star, H.P. Marijnissen, A.E. van den Berg-Blok, J.A. Versteeg, K.A. Franken, H.S. Reinhold, Destruction of rat mammary tumor and normal tissue microcirculation by hematoporphyrin derivative photoradiation observed in vivo in sandwich observation chambers, Cancer Res. 46 (1986) 2532-2540.

[172] M.W. Reed, F.N. Miller, T.J. Wieman, M.T. Tseng, C.G. Pietsch, The effect of photodynamic therapy on the microcirculation, J. Surg. Res. 45 (1988) 452-459.

[173] G. Krosl, M. Korbelik, G.J. Dougherty, Induction of immune cell infiltration into murine SCCVII tumour by photofrin-based photodynamic therapy, Br. J. Cancer 71 (1995) 549-555.

[174] S.O. Gollnick, X. Liu, B. Owczarczak, D.A. Musser, B.W. Henderson, Altered expression of interleukin 6 and interleukin 10 as a result of photodynamic therapy in vivo, Cancer Res. 57 (1997) 3904-3909.

[175] E. Moilanen, P. Vuorinen, H. Kankaanranta, T. Metsa-Ketela, H. Vapaatalo, Inhibition by nitric oxide-donors of human polymorphonuclear leucocyte functions, Br. J. Pharmacol. 109 (1993) $852-858$.

[176] H.H. Schmidt, U. Walter, NO at work, Cell 78 (1994) 919-925.

[177] D.G. Hirst, F.W. Flitney, in: R. Bicknell, C.E. Lewis, N. Ferrara (Eds.), Tumor Angiogenesis, Oxford Univ. Press, Oxford, 1997, pp. $153-167$.

[178] B.W. Henderson, T.M. Sitnik-Busch, L.A. Vaughan, Potentiation of photodynamic therapy antitumor activity in mice by nitric oxide synthase inhibition is fluence rate-dependent, Photochem. Photobiol. 70 (1999) 64-71.

[179] M. Korbelik, C.S. Parkins, H. Shibuya, I. Cecic, M.R. Stratford, D.J. Chaplin, Nitric oxide production by tumour tissue: impact on the response to photodynamic therapy, Br. J. Cancer 82 (2000) $1835-1843$.

[180] L. Liu, J.S. Stamler, NO: an inhibitor of cell death, Cell Death Differ6 (1999) 937-942.

[181] E.R. Gomes, T. Cruz, C.F. Lopes, A.P. Carvalho, C.B. Duarte, Photosensitization of lymphoblastoid cells with phthalocyanines at different saturating incubation times, Cell Biol. Toxicol. 15 (1999) $249-260$.

[182] M. Niziolek, W. Korytowski, A.W. Girotti, Chain-breaking antioxidant and cytoprotective action of nitric oxide on photodynamically stressed tumor cells, Photochem. Photobiol. 78 (2003) 262-270.

[183] E.R. Gomes, R.D. Almeida, A.P. Carvalho, C.B. Duarte, Nitric oxide modulates tumor cell death induced by photodynamic therapy through a cGMP-dependent mechanism, Photochem. Photobiol. 76 (2002) 423-430.

[184] Y.M. Kim, M.E. de Vera, S.C. Watkins, T.R. Billiar, Nitric oxide protects cultured rat hepatocytes from tumor necrosis factor-alphainduced apoptosis by inducing heat shock protein 70 expression, J. Biol. Chem. 272 (1997) 1402-1411.

[185] R. Foresti, R. Motterlini, The heme oxygenase pathway and its interaction with nitric oxide in the control of cellular homeostasis, Free Radic. Res. 31 (1999) 459-475.

[186] C.V. Suschek, V. Krischel, D. Bruch-Gerharz, D. Berendji, J. Krutmann, K.D. Kroncke, V. Kolb-Bachofen, Nitric oxide fully protects against UVA-induced apoptosis in tight correlation with Bcl-2 up-regulation, J. Biol. Chem. 274 (1999) 6130-6137.

[187] M. Niziolek, W. Korytowski, A.W. Girotti, Nitric oxide inhibition of free radical-mediated lipid peroxidation in photodynamically treated membranes and cells, Free Radic. Biol. Med. 34 (2003) 997-1005. 
[188] L. Chang, M. Karin, Mammalian MAP kinase signalling cascades, Nature 410 (2001) 37-40.

[189] T.J. Matos, C.B. Duarte, A.P. Carvalho, M.C. Lopes, in: L. Heilmeyer, P. Friedrich (Eds.), Protein Modules in Cellular Signalling, IOS Press, Amsterdam, 2001, pp. 12-28.

[190] J. Tao, J.S. Sanghera, S.L. Pelech, G. Wong, J.G. Levy, Stimulation of stress-activated protein kinase and p38 HOG1 kinase in murine keratinocytes following photodynamic therapy with benzoporphyrin derivative, J. Biol. Chem. 271 (1996) 27107-27115.

[191] L.O. Klotz, C. Fritsch, K. Briviba, N. Tsacmacidis, F. Schliess, H. Sies, Activation of JNK and p38 but not ERK MAP kinases in human skin cells by 5 -aminolevulinate photodynamic therapy, Cancer Res. 58 (1998) 4297-4300.

[192] T.W. Wong, E. Tracy, A.R. Oseroff, H. Baumann, Photodynamic therapy mediates immediate loss of cellular responsiveness to cytokines and growth factors, Cancer Res. 63 (2003) 3812-3818.

[193] L. Xue, J. He, N.L. Oleinick, Promotion of photodynamic therapyinduced apoptosis by stress kinases, Cell Death Differ. 6 (1999) $855-864$.

[194] S. Zhuang, I.E. Kochevar, Singlet oxygen-induced activation of Akt/ protein kinase B is independent of growth factor receptors, Photochem. Photobiol. 78 (2003) 361-371.

[195] Z. Tong, G. Singh, A.J. Rainbow, Sustained activation of the extracellular signal regulated kinase pathway protects cells from photofrin-mediated photodynamic therapy, Cancer Res. 62 (2002) $5528-5535$.

[196] Z. Tong, G. Singh, K. Valerie, A.J. Rainbow, Activation of the stress-activated JNK and p38 MAPK kinases in human cells by Photofrin-mediated photodynamic therapy, J. Photochem. Photobiol., B 71 (2003) 77-85.

[197] L.Y. Xue, J. He, N.L. Oleinick, Rapid tyrosine phosphorylation of HS1 in the response of mouse lymphoma L5178Y-R cells to photodynamic treatment sensitized by the phthalocyanine Pc 4, Photochem. Photobiol. 66 (1997) 105-113.

[198] D.J. Granville, J.G. Levy, D.W. Hunt, Photodynamic treatment with benzoporphyrin derivative monoacid ring A produces protein tyrosine phosphorylation events and DNA fragmentation in murine P815 cells, Photochem. Photobiol. 67 (1998) 358-362.

[199] D.B. Pereira, A.P. Carvalho, C.B. Duarte, Genistein inhibits $\mathrm{Ca}^{2+}$ influx and glutamate release from hippocampal synaptosomes: putative non-specific effects, Neurochem. Int. 42 (2003) 179-188.

[200] D. Kitamura, H. Kaneko, Y. Miyagoe, T. Ariyasu, T. Watanabe, Isolation and characterization of a novel human gene expressed specifically in the cells of hematopoietic lineage, Nucleic Acids Res. 17 (1989) 9367-9379.

[201] T. Fukuda, D. Kitamura, I. Taniuchi, Y. Maekawa, L.E. Benhamou, P. Sarthou, T. Watanabe, Restoration of surface IgM-mediated apoptosis in an anti-IgM-resistant variant of WEHI-231 lymphoma cells by HS1, a protein-tyrosine kinase substrate, Proc. Natl. Acad. Sci. U. S. A. 92 (1995) $7302-7306$.

[202] I. Taniuchi, D. Kitamura, Y. Maekawa, T. Fukuda, H. Kishi, T. Watanabe, Antigen receptor-induced clonal expansion and deletion of lymphocytes are impaired in mice lacking HS1 protein, a substrate of the antigen-receptor-coupled tyrosine kinases, EMBO J. 14 (1995) 3664-3678.

[203] P. Agostinis, A. Vandenbogaerde, A. Donella-Deana, L.A. Pinna, K.T. Lee, J. Goris, W. Merlevede, J.R. Vandenheede, P. De Witte, Photosensitized inhibition of growth factor regulated protein kinases by hypericin, Biochem. Pharmacol. 49 (1995) 1615-1622.

[204] D.C. Spaulding, B.O. Spaulding, Epidermal growth factor receptor expression and measurement in solid tumors, Semin. Oncol. 29 (2002) 45-54

[205] G. Nunez, L. del Peso, Linking extracellular survival signals and the apoptotic machinery, Curr. Opin. Neurobiol. 8 (1998) 613-618.

[206] J. Downward, Mechanisms and consequences of activation of protein kinase B/Akt, Curr. Opin. Cell Biol. 10 (1998) 262-267.

[207] E.S. Kandel, N. Hay, The regulation and activities of the multifunc- tional serine/threonine kinase Akt/PKB, Exp. Cell Res. 253 (1999) $210-229$.

[208] J. Schlessinger, Cell signaling by receptor tyrosine kinases, Cell 103 (2000) 211-225.

[209] T. Fukada, Y. Yoshida, K. Nishida, T. Ohtani, T. Shirogane, M. Hibi, T. Hirano, Signaling through Gp130: toward a general scenario of cytokine action, Growth Factors 17 (1999) 81-91.

[210] T. Hirano, K. Ishihara, M. Hibi, Roles of STAT3 in mediating the cell growth, differentiation and survival signals relayed through the IL-6 family of cytokine receptors, Oncogene 19 (2000) $2548-2556$.

[211] T. Ishibashi, H. Kimura, T. Uchida, S. Kariyone, P. Friese, S.A. Burstein, Human interleukin 6 is a direct promoter of maturation of megakaryocytes in vitro, Proc. Natl. Acad. Sci. U. S. A. 86 (1989) 5953-5957.

[212] S.L. Grant, C.G. Begley, The oncostatin M signalling pathway: reversing the neoplastic phenotype? Mol. Med. Today 5 (1999) 406-412.

[213] P. Klausen, L. Pedersen, J. Jurlander, H. Baumann, Oncostatin $\mathrm{M}$ and interleukin 6 inhibit cell cycle progression by prevention of p27kip1 degradation in HepG2 cells, Oncogene 19 (2000) $3675-3683$.

[214] E. Shaulian, M. Karin, AP-1 as a regulator of cell life and death, Nat. Cell Biol. 4 (2002) E131-E136.

[215] M. Ameyar, M. Wisniewska, J.B. Weitzman, A role for AP-1 in apoptosis: the case for and against, Biochimie 85 (2003) 747-752.

[216] M.C. Luna, S. Wong, C.J. Gomer, Photodynamic therapy mediated induction of early response genes, Cancer Res. 54 (1994) $1374-1380$.

[217] G. Kick, G. Messer, G. Plewig, P. Kind, A.E. Goetz, Strong and prolonged induction of c-jun and c-fos proto-oncogenes by photodynamic therapy, Br. J. Cancer 74 (1996) 30-36.

[218] G. Kick, G. Messer, A. Goetz, G. Plewig, P. Kind, Photodynamic therapy induces expression of interleukin 6 by activation of AP-1 but not NF-kappa B DNA binding, Cancer Res. 55 (1995) 2373-2379.

[219] S.W. Ryter, C.J. Gomer, Nuclear factor kappa B binding activity in mouse L1210 cells following photofrin II-mediated photosensitization, Photochem. Photobiol. 58 (1993) 753-756.

[220] S. Ghosh, M.J. May, E.B. Kopp, NF-kappa B and Rel proteins: evolutionarily conserved mediators of immune responses, Annu. Rev. Immunol. 16 (1998) 225-260.

[221] H.L. Pahl, Activators and target genes of Rel/NF-kappaB transcription factors, Oncogene 18 (1999) 6853-6866.

[222] M. Barkett, T.D. Gilmore, Control of apoptosis by Rel/NF-kappaB transcription factors, Oncogene 18 (1999) 6910-6924.

[223] B. Kaltschmidt, C. Kaltschmidt, T.G. Hofmann, S.P. Hehner, W. Droge, M.L. Schmitz, The pro- or anti-apoptotic function of NFkappaB is determined by the nature of the apoptotic stimulus, Eur. J. Biochem. 267 (2000) 3828-3835.

[224] J. Kucharczak, M.J. Simmons, Y. Fan, C. Gelinas, To be, or not to be: NF-kappaB is the answer-role of Rel/NF-kappaB in the regulation of apoptosis, Oncogene 22 (2003) 8961-8982.

[225] B. Piret, S. Legrand-Poels, C. Sappey, J. Piette, NF-kappa B transcription factor and human immunodeficiency virus type 1 (HIV-1) activation by methylene blue photosensitization, Eur. J. Biochem. 228 (1995) 447-455.

[226] S. Legrand-Poels, V. Bours, B. Piret, M. Pflaum, B. Epe, B. Rentier, J. Piette, Transcription factor NF-kappa B is activated by photosensitization generating oxidative DNA damages, J. Biol. Chem. 270 (1995) 6925-6934.

[227] C. Volanti, J.Y. Matroule, J. Piette, Involvement of oxidative stress in NF-kappaB activation in endothelial cells treated by photodynamic therapy, Photochem. Photobiol. 75 (2002) 36-45.

[228] J.Y. Matroule, A.C. Hellin, P. Morliere, A.S. Fabiano, R. Santus, M.P. Merville, J. Piette, Role of nuclear factor-kappa B in colon cancer cell apoptosis mediated by aminopyropheophorbide photosensitization, Photochem. Photobiol. 70 (1999) 540-548. 
[229] N. Ahmad, D.K. Feyes, R. Agarwal, H. Mukhtar, Photodynamic therapy results in induction of WAF1/CIP1/P21 leading to cell cycle arrest and apoptosis, Proc. Natl. Acad. Sci. U. S. A. 95 (1998) 6977-6982.

[230] V.C. Colussi, D.K. Feyes, J.W. Mulvihill, Y.S. Li, M.E. Kenney, C.A. Elmets, N.L. Oleinick, H. Mukhtar, Phthalocyanine 4 (Pc 4) photodynamic therapy of human OVCAR-3 tumor xenografts, Photochem. Photobiol. 69 (1999) 236-241.

[231] C.M. Whitacre, D.K. Feyes, T. Satoh, J. Grossmann, J.W. Mulvihill, H. Mukhtar, N.L. Oleinick, Photodynamic therapy with the phthalocyanine photosensitizer Pc 4 of SW480 human colon cancer xenografts in athymic mice, Clin. Cancer Res. 6 (2000) 2021-2027.

[232] J.M. Trimarchi, J.A. Lees, Sibling rivalry in the E2F family, Nat. Rev. Mol. Cell Biol. 3 (2002) 11-20.

[233] N. Ahmad, S. Gupta, H. Mukhtar, Involvement of retinoblastoma $(\mathrm{Rb})$ and $\mathrm{E} 2 \mathrm{~F}$ transcription factors during photodynamic therapy of human epidermoid carcinoma cells A431, Oncogene 18 (1999) $1891-1896$.

[234] C. Bowen, S. Spiegel, E.P. Gelmann, Radiation-induced apoptosis mediated by retinoblastoma protein, Cancer Res. 58 (1998) $3275-3281$.

[235] E.W. Lam, R.J. Watson, An E2F-binding site mediates cell-cycle regulated repression of mouse B-myb transcription, EMBO J. 12 (1993) 2705-2713.

[236] S.J. Weintraub, K.N. Chow, R.X. Luo, S.H. Zhang, S. He, D.C. Dean, Mechanism of active transcriptional repression by the retinoblastoma protein, Nature 375 (1995) 812-815.

[237] J.W. Harbour, D.C. Dean, Rb function in cell-cycle regulation and apoptosis, Nat. Cell Biol. 2 (2000) E65-E67.

[238] C.J. Gomer, M. Luna, A. Ferrario, N. Rucker, Increased transcription and translation of heme oxygenase in Chinese hamster fibroblasts following photodynamic stress or Photofrin II incubation, Photochem. Photobiol. 53 (1991) 275-279.

[239] M.D. Maines, Heme oxygenase: function, multiplicity, regulatory mechanisms, and clinical applications, FASEB J. 2 (1988) $2557-2568$.

[240] B.A. Schacter, Heme catabolism by heme oxygenase: physiology, regulation, and mechanism of action, Semin. Hematol. 25 (1988) $349-369$.

[241] R. Stocker, Y. Yamamoto, A.F. McDonagh, A.N. Glazer, B.N. Ames, Bilirubin is an antioxidant of possible physiological importance, Science 235 (1987) 1043-1046.

[242] K.K. Elbirt, H.L. Bonkovsky, Heme oxygenase: recent advances in understanding its regulation and role, Proc. Assoc. Am. Physicians 111 (1999) 438-447.

[243] J. Alam, Z. Den, Distal AP-1 binding sites mediate basal level enhancement and TPA induction of the mouse heme oxygenase-1 gene, J. Biol. Chem. 267 (1992) 21894-21900.

[244] C.J. Gomer, A. Ferrario, N. Rucker, S. Wong, A.S. Lee, Glucose regulated protein induction and cellular resistance to oxidative stress mediated by porphyrin photosensitization, Cancer Res. 51 (1991) $6574-6579$.

[245] C.J. Gomer, S.W. Ryter, A. Ferrario, N. Rucker, S. Wong, A.M. Fisher, Photodynamic therapy-mediated oxidative stress can induce expression of heat shock proteins, Cancer Res. 56 (1996) $2355-2360$.

[246] P.M. Curry, J.G. Levy, Stress protein expression in murine tumor cells following photodynamic therapy with benzoporphyrin derivative, Photochem. Photobiol. 58 (1993) 374-379.

[247] R.I. Morimoto, Cells in stress: transcriptional activation of heat shock genes, Science 259 (1993) 1409-1410.

[248] M.C. Luna, A. Ferrario, S. Wong, A.M. Fisher, C.J. Gomer, Photodynamic therapy mediated oxidative stress as a molecular switch for the temporal expression of genes ligated to the human heat shock promoter, Cancer Res. 60 (2000) 1637-1644.

[249] S. Mitra, E.M. Goren, J.G. Frelinger, T.H. Foster, Activation of heat shock protein 70 promoter with mTHPC-photodynamic therapy reported by green fluorescent protein in vitro and in vivo, Photochem. Photobiol. 78 (2003) 615-622.

[250] M. Nonaka, H. Ikeda, T. Inokuchi, Inhibitory effect of heat shock protein 70 on apoptosis induced by photodynamic therapy in vitro, Photochem. Photobiol. 79 (2004) 94-98.

[251] A. Saleh, S.M. Srinivasula, L. Balkir, P.D. Robbins, E.S. Alnemri, Negative regulation of the Apaf-1 apoptosome by Hsp70, Nat. Cell Biol. 2 (2000) 476-483.

[252] H.M. Beere, B.B. Wolf, K. Cain, D.D. Mosser, A. Mahboubi, T. Kuwana, P. Tailor, R.I. Morimoto, G.M. Cohen, D.R. Green, Heatshock protein 70 inhibits apoptosis by preventing recruitment of procaspase-9 to the Apaf-1 apoptosome, Nat. Cell Biol. 2 (2000) $469-475$.

[253] P. Pandey, A. Nakazawa, Y. Ito, R. Datta, S. Kharbanda, D. Kufe, Requirement for caspase activation in monocytic differentiation of myeloid leukemia cells, Oncogene 19 (2000) 3941-3947.

[254] J. Golab, D. Nowis, M. Skrzycki, H. Czeczot, A. Baranczyk-Kuzma, G.M. Wilczynski, M. Makowski, P. Mroz, K. Kozar, R. Kaminski, A. Jalili, M. Kopec, T. Grzela, M. Jakobisiak, Antitumor effects of photodynamic therapy are potentiated by 2-methoxyestradiol. A superoxide dismutase inhibitor, J. Biol. Chem. 278 (2003) 407-414.

[255] H. Das, T. Koizumi, T. Sugimoto, S. Yamaguchi, K. Hasegawa, Y. Tenjin, R. Nishimura, Induction of apoptosis and manganese superoxide dismutase gene by photodynamic therapy in cervical carcinoma cell lines, Int. J. Clin. Oncol. 5 (2000) 97-103.

[256] L. Miccoli, A. Beurdeley-Thomas, G. De Pinieux, F. Sureau, S. Oudard, B. Dutrillaux, M.F. Poupon, Light-induced photoactivation of hypericin affects the energy metabolism of human glioma cells by inhibiting hexokinase bound to mitochondria, Cancer Res. 58 (1998) 5777-5786.

[257] D. Grebenova, P. Halada, J. Stulik, V. Havlicek, Z. Hrkal, Protein changes in HL60 leukemia cells associated with 5-aminolevulinic acid-based photodynamic therapy. Early effects on endoplasmic reticulum chaperones, Photochem. Photobiol. 72 (2000) 16-22.

[258] C. Anderson, S. Hrabovsky, Y. McKinley, K. Tubesing, H.P. Tang, R. Dunbar, H. Mukhtar, C.A. Elmets, Phthalocyanine photodynamic therapy: disparate effects of pharmacologic inhibitors on cutaneous photosensitivity and on tumor regression, Photochem. Photobiol. 65 (1997) 895-901.

[259] S. Evans, W. Matthews, R. Perry, D. Fraker, J. Norton, H.I. Pass, Effect of photodynamic therapy on tumor necrosis factor production by murine macrophages, J. Natl. Cancer Inst. 82 (1990) $34-39$.

[260] S.E. Jones, C. Jomary, Clusterin, Int. J. Biochem. Cell Biol. 34 (2002) 427-431.

[261] K. Kalka, N. Ahmad, T. Criswell, D. Boothman, H. Mukhtar, Upregulation of clusterin during phthalocyanine 4 photodynamic therapy-mediated apoptosis of tumor cells and ablation of mouse skin tumors, Cancer Res. 60 (2000) 5984-5987.

[262] M. Oren, Decision making by p53: life, death and cancer, Cell Death Differ. 10 (2003) 431-442

[263] A.M. Fisher, A. Ferrario, N. Rucker, S. Zhang, C.J. Gomer, Photodynamic therapy sensitivity is not altered in human tumor cells after abrogation of p53 function, Cancer Res. 59 (1999) 331-335.

[264] Z. Tong, G. Singh, A.J. Rainbow, The role of the p53 tumor suppressor in the response of human cells to photofrin-mediated photodynamic therapy, Photochem. Photobiol. 71 (2000) 201-210.

[265] A. Hajri, S. Wack, C. Meyer, M.K. Smith, C. Leberquier, M. Kedinger, M. Aprahamian, In vitro and in vivo efficacy of photofrin and pheophorbide a, a bacteriochlorin, in photodynamic therapy of colonic cancer cells, Photochem. Photobiol. 75 (2002) $140-148$

[266] S.O. Gollnick, S.S. Evans, H. Baumann, B. Owczarczak, P. Maier, L. Vaughan, W.C. Wang, E. Unger, B.W. Henderson, Role of cytokines in photodynamic therapy-induced local and systemic inflammation, Br. J. Cancer 88 (2003) 1772-1779

[267] J. Sun, I. Cecic, C.S. Parkins, M. Korbelik, Neutrophils as inflam- 
matory and immune effectors in photodynamic therapy-treated mouse SCCVII tumours, Photochem. Photobiol. Sci. 1 (2002) 690-695.

[268] M. Korbelik, G. Krosl, J. Krosl, G.J. Dougherty, The role of host lymphoid populations in the response of mouse EMT6 tumor to photodynamic therapy, Cancer Res. 56 (1996) 5647-5652.

[269] E. Di Carlo, G. Forni, P. Lollini, M.P. Colombo, A. Modesti, P. Musiani, The intriguing role of polymorphonuclear neutrophils in antitumor reactions, Blood 97 (2001) 339-345.

[270] I. Cecic, M. Korbelik, Mediators of peripheral blood neutrophilia induced by photodynamic therapy of solid tumors, Cancer Lett. 183 (2002) 43-51.

[271] A. Ferrario, K.F. von Tiehl, N. Rucker, M.A. Schwarz, P.S. Gill, C.J. Gomer, Antiangiogenic treatment enhances photodynamic therapy responsiveness in a mouse mammary carcinoma, Cancer Res. 60 (2000) 4066-4069.

[272] J.A. Forsythe, B.H. Jiang, N.V. Iyer, F. Agani, S.W. Leung, R.D. Koos, G.L. Semenza, Activation of vascular endothelial growth factor gene transcription by hypoxia-inducible factor 1, Mol. Cell Biol. 16 (1996) 4604-4613.

[273] C.J. Schofield, P.J. Ratcliffe, Oxygen sensing by HIF hydroxylases, Nat. Rev. Mol. Cell Biol. 5 (2004) 343-354.

[274] D. Shweiki, A. Itin, D. Soffer, E. Keshet, Vascular endothelial growth factor induced by hypoxia may mediate hypoxia-initiated angiogenesis, Nature 359 (1992) 843-845.

[275] A. Ferrario, C.F. Chantrain, K. von Tiehl, S. Buckley, N. Rucker, D.R. Shalinsky, H. Shimada, Y.A. DeClerck, C.J. Gomer, The matrix metalloproteinase inhibitor prinomastat enhances photodynamic therapy responsiveness in a mouse tumor model, Cancer Res. 64 (2004) 2328-2332.

[276] H. Guo, S. Zucker, M.K. Gordon, B.P. Toole, C. Biswas, Stimulation of matrix metalloproteinase production by recombinant extracellular matrix metalloproteinase inducer from transfected Chinese hamster ovary cells, J. Biol. Chem. 272 (1997) 24-27.

[277] S. Wojtowicz-Praga, Clinical potential of matrix metalloprotease inhibitors, Drugs R\&D 1 (1999) 117-129.

[278] D. Kessel, Y. Luo, P. Mathieu, J.J. Reiners Jr., Determinants of the apoptotic response to lysosomal photodamage, Photochem. Photobiol. 71 (2000) 196-200.

[279] W. Xiang, H. Weingandt, F. Liessmann, S. Klein, H. Stepp, R. Baumgartner, P. Hillemanns, Photodynamic effects induced by aminolevulinic acid esters on human cervical carcinoma cells in culture, Photochem. Photobiol. 74 (2001) 617-623.

[280] M. Subbarayan, U.O. Hafeli, D.K. Feyes, J. Unnithan, S.N. Emancipator, H. Mukhtar, A simplified method for preparation of $99 \mathrm{mTc}-a n n e x i n \mathrm{~V}$ and its biologic evaluation for in vivo imaging of apoptosis after photodynamic therapy, J. Nucl. Med. 44 (2003) $650-656$.

[281] B.B. Noodt, K. Berg, T. Stokke, Q. Peng, J.M. Nesland, Apoptosis and necrosis induced with light and 5-aminolaevulinic acid-derived protoporphyrin IX, Br. J. Cancer 74 (1996) 22-29.

[282] J. Webber, Y. Luo, R. Crilly, D. Fromm, D. Kessel, An apoptotic response to photodynamic therapy with endogenous protoporphyrin in vivo, J. Photochem. Photobiol., B 35 (1996) 209-211.

[283] L. Lilge, M. Portnoy, B.C. Wilson, Apoptosis induced in vivo by photodynamic therapy in normal brain and intracranial tumour tissue, Br. J. Cancer 83 (2000) 1110-1117.

[284] M.L. Agarwal, M.E. Clay, E.J. Harvey, H.H. Evans, A.R. Antunez, N.L. Oleinick, Photodynamic therapy induces rapid cell death by apoptosis in L5178Y mouse lymphoma cells, Cancer Res. 51 (1991) 5993-5996.

[285] S.I. Zaidi, N.L. Oleinick, M.T. Zaim, H. Mukhtar, Apoptosis during photodynamic therapy-induced ablation of RIF-1 tumors in $\mathrm{C} 3 \mathrm{H}$ mice: electron microscopic, histopathologic and biochemical evidence, Photochem. Photobiol. 58 (1993) 771-776.

[286] D.J. Ball, Y. Luo, D. Kessel, J. Griffiths, S.B. Brown, D.I. Vernon, The induction of apoptosis by a positively charged methylene blue derivative, J. Photochem. Photobiol., B 42 (1998) $159-163$

[287] M.A. Laukka, K.K. Wang, J.A. Bonner, Apoptosis occurs in lymphoma cells but not in hepatoma cells following ionizing radiation and photodynamic therapy, Dig. Dis. Sci. 39 (1994) 2467-2475.

[288] K.W. Woodburn, Q. Fan, D.R. Miles, D. Kessel, Y. Luo, S.W. Young, Localization and efficacy analysis of the phototherapeutic lutetium texaphyrin (PCI-0123) in the murine EMT6 sarcoma model, Photochem. Photobiol. 65 (1997) 410-415.

[289] J.Y. Chen, N.K. Mak, J.M. Wen, W.N. Leung, S.C. Chen, M.C. Fung, N.H. Cheung, A comparison of the photodynamic effects of temoporfin (mTHPC) and MC540 on leukemia cells: efficacy and apoptosis, Photochem. Photobiol. 68 (1998) 545-554.

[290] R. Agarwal, N.J. Korman, R.R. Mohan, D.K. Feyes, S. Jawed, M.T. Zaim, H. Mukhtar, Apoptosis is an early event during phthalocyanine photodynamic therapy-induced ablation of chemically induced squamous papillomas in mouse skin, Photochem. Photobiol. 63 (1996) $547-552$.

[291] A.M. Fisher, K. Danenberg, D. Banerjee, J.R. Bertino, P. Danenberg, C.J. Gomer, Increased photosensitivity in HL60 cells expressing wild-type p53, Photochem. Photobiol. 66 (1997) 265-270.

[292] H. Tajiri, N. Shinomiya, A. Hayakawa, Y. Matsumoto, S. Yoshida, Photodynamic therapy-induced rapid cell death by apoptosis in human pancreatic carcinoma transplanted-into nude mice, J. Clin. Biochem. Nutr. 21 (1996) 29-37.

[293] X.Y. He, R.A. Sikes, S. Thomsen, L.W. Chung, S.L. Jacques, Photodynamic therapy with photofrin II induces programmed cell death in carcinoma cell lines, Photochem. Photobiol. 59 (1994) $468-473$

[294] I.E. Kochevar, M.C. Lynch, S. Zhuang, C.R. Lambert, Singlet oxygen, but not oxidizing radicals, induces apoptosis in HL-60 cells, Photochem. Photobiol. 72 (2000) 548-553.

[295] J.F. Tremblay, S. Dussault, G. Viau, F. Gad, M. Boushira, R. Bissonnette, Photodynamic therapy with toluidine blue in Jurkat cells: cytotoxicity, subcellular localization and apoptosis induction, Photochem. Photobiol. Sci. 1 (2002) 852-856. 